\title{
A geotouristic valuation of the Marsyangdi Valley in the Annapurna Himal region and its potential for the development of geotourist attractions
}

\author{
Ocena geoturystyczna doliny Marsyangdi regionu Annapurny Himal \\ i jej potencjał w tworzeniu atrakcji geoturystycznych
}

\author{
Janusz Lach \\ University of Wroclaw, Department of Regional Geography and Tourism, \\ pl. Uniwersytecki 1, 50-137 Wroclaw, \\ e-mail: janusz.lach@uwr.edu.pl
}
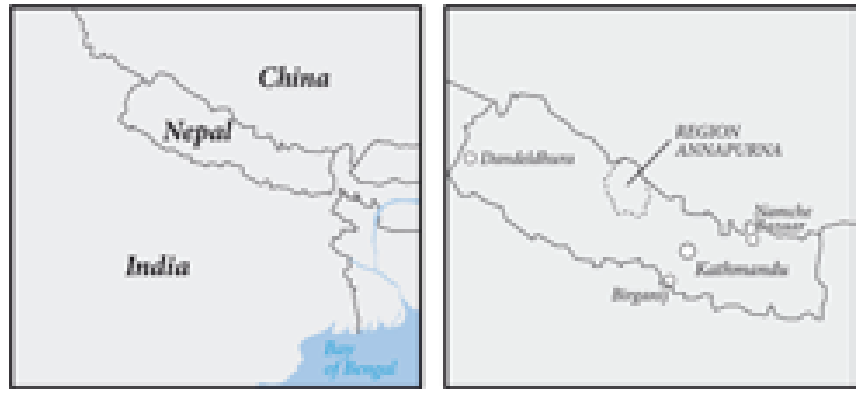

\begin{abstract}
The Marsyangdi Valley in the Annapurna Himal region is one of the most popular tourist-trekking attractions in Nepal. The performed evaluation of geotourist (geomorphological and hydrographic) objects and phenomena demonstrated a wide range of forms and, correspondingly, a huge potential for the development of geotourist attractions. The structure of The Marsyangdi Valley, which is a representative of a valley region of the High Himalaya, situated on metamorphic rocks, shows the co-existence of three major geomorphic processes: glacial, fluvial and slope, which determine specific landscape forms. Since the late 20th century, the landscape has been heavily affected by anthropogenic factors (grazing, land cultivation, settlement), reaching as far as 3500 meters above sea level, as well as by the dynamic growth and development of tourism. Expanding tourist infrastructure contributes to, inter alia, the degradation of the narrow valley bottom (tourist accommodation) and to increased mass movement on tourist trails. Despite its negative effects, tourism also exerts a positive influence on the preservation of the cultural heritage (sacred sites), which largely dominate the landscape and are a significant tourist attraction. The research was instrumental in defining the Marsyangdi Valley, characteristic of a geomorphological trail, as an excellent and qualified attraction in geotourist-exploratory tourism.
\end{abstract}

Key words: the Himalayas, Annapurna Himal, Marsyangdi valley, geotourist valuation, trekking

Treść: Dolina Marsyangdi należąca do regionu Annapurny Himal jest jedna z najpopularniejszych atrakcji turystycznych - trekkingowych Nepalu. Przeprowadzona pod katem obiektów i zjawisk geoturystycznych (geomorfologicznych $i$ hydrograficznych) ocena ukazała jej duża różnorodność form, a tym samym duży potencjat atrakcji geoturystycznych. W strukturze doliny Marsyangdi, będącej przyktadem dolin obszaru Himalajów Wysokich, wyróżniono wspótistnienie trzech głównych procesów geomorfologicznych: glacjalnych, fluwialnych i stokowych, warunkujacych specyficzne formy o wysokich walorach krajobrazowych, które od końca XX wieku podlegaja szybkiej destrukcji w wyniku antropopresji. Czynniki antropogeniczne tj. hodowla, uprawa, czy osadnictwo siegajace nawet do 3500 m n.p.m., a obecnie jeszcze turystyka, przyczyniaja się do wzrostu aktywności procesów geomorfologicznych m.in. ruchów masowych, w tym na szlakach turystycznych. Jednakże oprócz negatywnego wptywu turystyki na uwage zastuguje jej pozytywne oddziaływanie w szczególności w kwestii ochrony dziedzictwa kulturowego, czego przykładem sq odnawiane obiekty sakralne stanowiace niezwykta dominante krajobrazu oraz istotna atrakcje turystyczna. Badania pozwolity zdefiniować obszar Doliny Marsyangdi jako odpowiedni do uprawiania turystyki kwalifikowanej, poznawczej-geoturystyki.

Slowa kluczowe: Himalaje, Annapurna Himal, dolina Marsyangdi, waloryzacja geoturystyczna, trekking

\section{Introduction}

The magnificent landscape of the highest mountains of the globe the Himalayas - is an object of scientific and tourist interest for people from all over the world. Due to its relative safety, Nepal is the country which has become the hub of experienced tourism e.g. mountaineering, trekking or rafting. For this purpose, a number of mountainous regions of high profile landscape and cultural values have been selected and assigned, including Kangchendzongi, Khumbu Himal, Rolwaling Himal, Langtang Valley, Gorkha Himal and Ganesh Himal and the Annapurna Himal region.

The object of the study is to show the landscape values of the Marsyangdi Valley in the context of potential geotourist attractions and cultural factors and their effect on the structure of sustainable tourism. Defining the predominant form of tourism in the Marsyangdi Valley region, which is currently described as a qualified - trekking tourism region, becomes an issue in the context of the relations under examination. Is the potential of attractions presented, especially geomorphic ones, enough to allow the Marsyangdi Valley region to be defined as geotourist region and granted the status 
of geotourist trails. The research refers to a significant aspect of geotourism - setting new trends in adventure tourism in high mountain areas. In this context, geotourism is a field of tourism defined as exploratory tourism aimed at discovering geological objects and processes, experiencing feelings and aesthetic impressions, by way of activities, which are determined by specialist knowledge and equipment (Słomka, Kicińska-Świderska, 2004; Kowalczyk, 2010). However, the essence of geotourism is not solely shaped by geological objects and processes, but also by other phenomena as well: history of geological discoveries, the role of stone in architecture (Osadczuk, Osadczuk, 2008) and, in relation to the completed research, also by geomorphological processes. Geotourist analyses involve a mountainous stretch $(90 \mathrm{~km})$ of the Marsyangdi Valley of a highly complex post-glacio-fluvial structure. Complex natural exogenic factors with very clear morphology and endogenic factors, earthquakes, exposed the dynamism of the valley land relief in the landscape, which is of keen interest to geographers (Lajczak, 2007). Anthropogenic factors, whose intensity of transforming the land relief commenced in the 1990s, add to the complexity of the landscape. Over the period in question, due to intensive development of agriculture reaching 4000 meters above sea level and spread of qualified tourism, especially trekking and rafting, the most significant landscape transformations have occurred. Elements of geotourist valuation of the Marsyangdi Valley included: diverse structure of the processes taking place in relief, hydrographic network, with a focus on changing riverbed structure, location of waterfalls and lakes, flora structure and architecture of cultural objects, closely linked to geological conditions. The material outcome of all the activities undertaken is a map of geotourist and morphological attractions in the Marsyangdi Valley (Fig. 1).

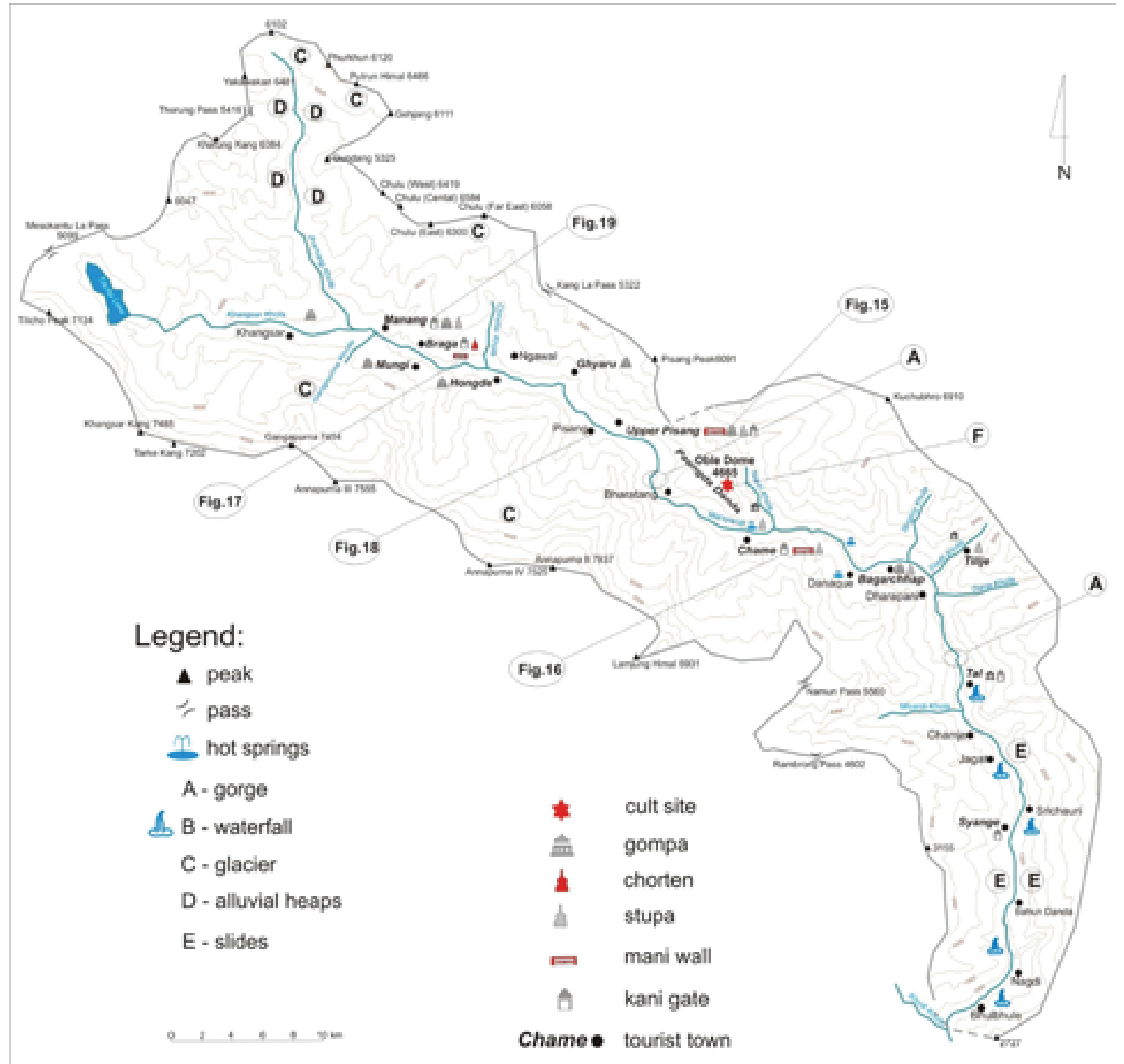

Fig. 1. Map of geotourist and morphological attractions in the Marsyangdi valley in the High Himalayas, photo J. Łach • Mapa atrakcji geoturystyczno-morfologicznych doliny Marsyangdi na obszarze Himalajów Wysokich, fot. J. Łach 
The study is based on field observation of morphological forms, meteorological and natural phenomena, as well as cultural phenomena of the Annapurna Himal region. The study involved acquiring knowledge - by interviewing local people - about the structure and function of life of the inhabitants, making photographic documentation of natural and cultural forms with cartographic records. The differences in names of natural and cultural objects noted in the course of analyzing the source materials have been standardized using a tourist-cartographic map, Annapurna - trek around, Scale $1: 160000$ - Sherpa Maps 2004.

\section{Characteristics of the study area}

The Annapurna Himal region - one of the most popular tourist-trekking regions in the world - extends to central Nepal. Nepal is situated in the Asian Continent between latitude $26^{\circ} 22^{\prime}-30^{\circ} 27^{\prime} \mathrm{N}$ and longitude $80^{\circ} 4^{\prime}$ and $88^{\circ} 12^{\prime} \mathrm{E}$, covering an area of $147181 \mathrm{~km}^{2}$. Approximately $80 \%$ of this small area is a mountainous region of the Higher Himalayas, with 8 peaks exceeding 8,000 metres above sea level, including the highest of all - Mount Everest, at 8,848 metres above sea level, which is also known as Chomolungma in Tibetan and Sagarmatha in Nepali. The other eight-thousanders include: Kangechenjunga (8586 m), Lhotse (8516 m), Makalu (8463 m), Cho Oyu (8201 m), Dhaulagiri (8167 m), Manaslu (8156 m) and Annapurna (8091 m). To the south, the Great Himalayas come steeply down to become the Mahabharat Mountains $80-100 \mathrm{~km}$ wide. The mountains reach heights of 4300 metres. They are characterized by rich mountain relief, numerous river valleys, with rocky gorges. Further on lies a system of tectonic valleys with the largest one - the
Kathmandu Valley. The southernmost mountain range is the Sivalik Hills, rising to 1500 metres above sea level, and it is characterized by gentle hills and slopes. The alluvial Indo-Gangetic Plain, not exceeding heights of $360 \mathrm{~m}$, sets a clear morphological divide in the south (Modela, 2000).

The above-mentioned Annapurna region, central to the author's scientific interests, lies in the heart of the High Himalayas (Fig. 2).

The region covers an area of $7629 \mathrm{~km}^{2}$ and comprises the Annapurna Himal Massif and a part of the Mustang region (ntnc.org.np, 10.11.2015). The designated tourist region partly corresponds to the area of the Annapurna Conservation Area Project (ACAP) set up in 1986. The region consists of the following mountain ranges: Dhaulagiri Range (8167 m), Poon Hill (3193 m), southern Annapurna Range I, central Annapurna Range I (8091 m), together with Annapurna III (7555 m), Annapurna IV (7525 m), Annapurna II (7937 m) referred to as the Great Annapurna Ridge, changing subsequently into the Karpu Danda Range, Telbrung Danda and Rambrong Danda, Machhapuchhre Range (6993 m), southern Annapurna IV Range, Nilgiri Range (7061 m), Khatung Kang Range (6384 m), Gundang Range (6584 m), Pisang Range (6091 m), Kang Guru Range (6981 m), and the valleys: Kali Gandaki, Modi Khola, Seti Khola, Madi Khola together with the Marsyangdi Valley (Fig. 3).

The Annapurna Himal region is a part of Kali Gandaki drainage basin with major tributaries such as: Modi Khola, Seti Khola, Madi Khola and Marsyandi. One of the characteristic features of the rivers are long profiles displaying considerable differences in gradients, which give rise to significant fluctuations of water levels throughout the year. Maximum water flows are noted in the summer due to melting snow and glaciers and, also, as a result of the summer monsoon.

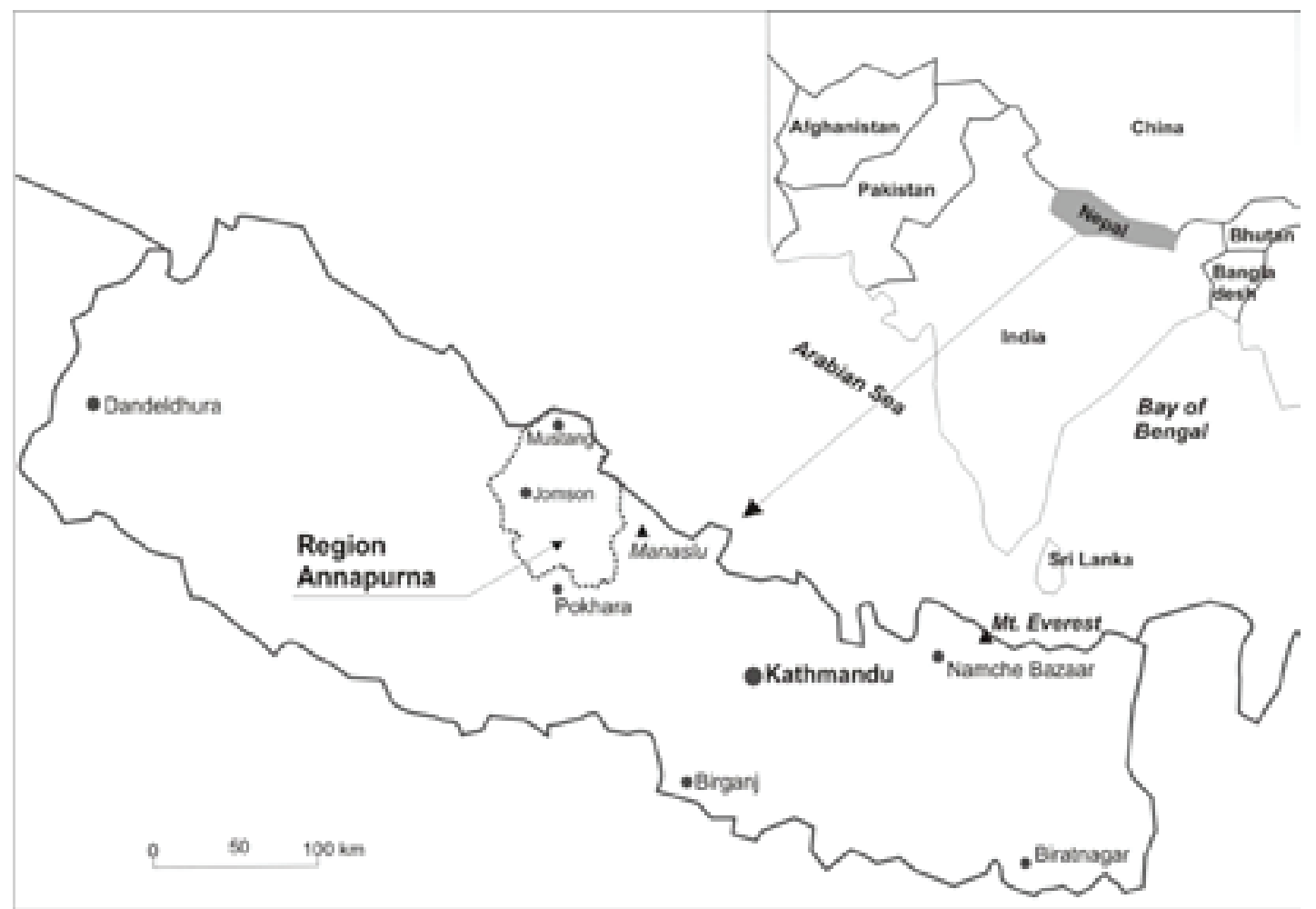

Fig. 2. Location of the Annapurna region in ACAP area, photo J. Łach • Lokalizacja regionu Annapurny w granicach ACAP, fot. J. Łach 
Apart from mountain peaks, the river valleys are obviously a significant element of the landscape in the Himalayan region. The landscape of the region is determined by the morphology of slopes, slope steepness, bottom width and steep river profiles. The landscape is further enriched by vegetation, with its altitudinal zonation determined by absolute altitude and precipitation, which shape vegetation zones from subtropical forest to crags. The subtropical vegetation zone rises to 2000 metres above sea level. The predominant type is tropical forest, with species like santalums (Santalum album), palm trees and bamboos. Deciduous forests including species like laurel trees, maples, chestnuts, oaks and magnolias are predominant at heights between $1700 \mathrm{~m}$ and $2700 \mathrm{~m}$. At $2700 \mathrm{~m}$, deciduous forests start to give way to coniferous forests, represented by Himalayan cedar (Cedrus deodara), Himalayan pine (Pinus walliachiana) and Morinda spruce (Picea smithiana). The subalpine zone, which is dotted with junipers and rhododendrons, extends above $3600 \mathrm{~m}$ and is covered by alpine tundra. The alpine zone occurs above the permanent snowline, at elevations of approximately $4000 \mathrm{~m}$. Grass-like plants, mosses and lichen are among the plants that are adapted to extremely harsh conditions at such altitudes. In the hot season, however, low growing flowers appear (Modela, 2000; Zgorzelski, 2009).

Considerable vertical differentiation also affects climate diversity: from hot, humid subtropical climate at an altitude of $800 \mathrm{~m}$ (Pokhara region), to temperate climate (up to about 3200 $\mathrm{m})$, to arctic climate, which is noted in the higher reaches of the mountains. Extensive climate diversity in such a relatively small area is influenced by differences in altitudes, orographic barriers and the arrangement thereof, latitude and monsoon; the summer monsoon in particular. Most precipitation occurs during the summer monsoons, with the annual value for the region at approximately $4000 \mathrm{~mm}$ (Makowski, 2006).

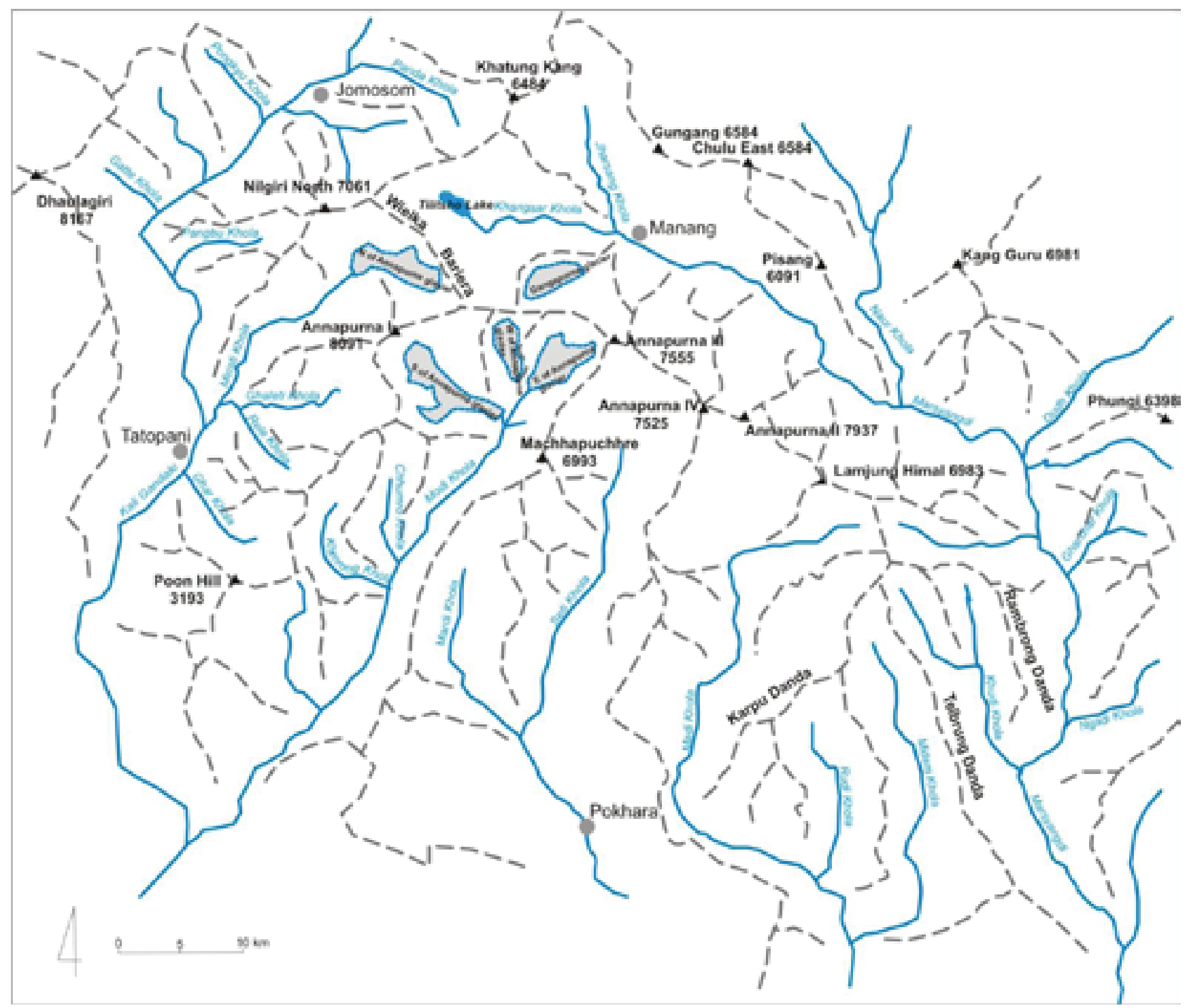

Fig. 3. Major mountain ranges and valleys of the Annapurna region. Own elaboration based on the Annapurna Himal map (based on Kurczab 2007, p. 240 - modified and supplemented) - Układ większych pasm i dolin górskich regionu Annapurny. Opracowanie własne na podstawie mapy Annapurna Himal (wg Kurczab 2007, s. 240 - zmodyfikowane i uzupełnione) 


\section{Morphological and hydrographic values of the landscape in the Marsyangdi Valley}

The formation of the High Himalayas is the result of the collision of the Indian and Euroasian plates in the Miocene, approximately 21-18 Ma, between the Burdigalian and Serravallian. However, the most substantial elevation of the High Himalayas took place in the period between the Tortonian - Gelasian, at around 11-4 Ma (Searle, 1996; Golonka at al., 2006; Golonka, 2009). The collision of the plates led to folding of terrain and, consequently, to elevation in the form of the Himalayas of Karakoram range. Subsequent intense geological and morphological processes in the region of the Himalayas occurred 2 million years ago, when the mountain range was uplifted causing alterations in drainage system and, as a result, in the course of river valleys (Xiao at al., 1988). The intensive elevation process of the young Himalayan mountain range is still going on today and, according to A. Scheidegger (1998), it is thrust upwards $5 \mathrm{~mm}$ every year. This results in morphological changes, particularly in intense deepening of river valleys and simultaneous elevation of coarse-grained material and emergence of mass movement forms in valley slopes and bottoms. A significant period in modelling the relief of the Himalayas is quaternary, with its variety of morpho-dynamic processes. Elevation exerted an immense influence on the formation of the cross and long section of the valley relief, its depth and slope steepness. The development of the quaternary relief was also affected by mountain glaciations 3.5 million years ago, when the average altitude of the emerging range exceeded 2500 metres above sea level (Scheidegger, 1998). Presently observable morphological forms inscribed in the landscape are the image of intensive quaternary activity.

The stretch of mountains of the Marsyangdi Valley (about $90 \mathrm{~km}$ ) under examination sits astride two tectonic zones of the Himalayas: High Himalaya, built of metamorphic rocks, like gneiss, crystal schist and migmatite and the Tibetian-Tehtys Himalaya, which is made of gneiss, schist, limestone and sandstone (Narkiewicz, 1997; Dahal, 2006). Geological base and its structure is visible in a number of exposures and rock outcrops found above cultivation zone.

The sources of Marsyangdi are at about $5800 \mathrm{~m}$ in an icy pass between the Yakawakan $6481 \mathrm{~m}$ and Phurkhun $6120 \mathrm{~m}$ peaks, where it initially flows under the name of Jharsang (Kone) Khola down to $3500 \mathrm{~m}$, where it meets the Khangsar Khola river and takes the new name Marsyangdi (Fig. 4).

Average inclination of the analyzed stretch of Marsyangdi is $5.5 \%$. The long profile of Marsyangdi channel displays numerous rapids with an increased gradient (Fig. 5), which is reflected in the landscape in the form of stretches of gorge (Fig. 6, position A on Fig. 1). The differentiation of the main channel can be observed in its horizontal structure. Up to the altitude of $3500 \mathrm{~m}$ (the place where Jharsang Kholi meets Khangsar Kholą), the channel is rectilinear or slightly sinuous Below the point of confluence, it changes into a sinuous channel, becomes braided in short stretches of the river and rectilinear in gorges.

In braided areas the channel of the river reaches the width of 80-100 $\mathrm{m}$ and is shaped by mid-channel bars and point bars. The Manang-Bhulbhule stretch is dominated by a meandering channel with fluvial terraces. The bottom is made up of a narrow flood terrace, around $2-3 \mathrm{~m}$ in height, a cut terrace, $3-5 \mathrm{~m}$ in height, and a cultivated and inhabited terrace, $10-25 \mathrm{~m}$ in height. The Marsyangdi channel is placed in fluvio-glacial and fluvial sediments. Fluvial deposits are built of visibly rounded coarse-grained block-gravel-boulder sediment.

Long profile analyses indicate a considerable difference in the shape of the valley. In the upper parts (Jharsang Valley), the cross profile is V-shaped, with a narrow bottom and prominent slopes covered with rock rubble. In central parts (from Manangu to Chame), the profile is U-shaped with a flat, broad bottom filled with glacial and fluvio-glacial sediment. This part resembles the Badlands landscape, due to erosion of lateral moraines (Fig. 7) and ground moraines, and, as a result of river erosion, cut deep alluvial, erosion channels (Fig. 8) up to $25 \mathrm{~m}$ in depth. In the lower part of the valley (from Chame to Bhulbhule), the long profile becomes $\mathrm{V}$-shaped again with a flat, narrow bottom.

The processes of elevation of the mountains give rise to continual deepening of the valleys which are, as A. Łajczak points out (2007), characterized by a complex long profile whose processes contribute to the deepening of the valleys and may reach over 3000 metres. The confirmation of research conducted in the neighbouring Tibet may be the gorge of Marsyangdi, at around 1000 metres above sea lev$\mathrm{el}$, around $2 \mathrm{~km}$ north of Tal (position A on Fig. 1). Here, we can observe a sudden change in the landscape of the bottom of the valley, which initially has a broad, flat bottom, split by a braided and meandering channel which, subsequently, abruptly becomes rectilinear. The bottom becomes narrower, with its structure changing into rocky bottom. The rate of flow of the water of Marsyangdi accelerates in gorges, boosting erosional downcutting, which is accompanied by water cascades and sizeable rock slides.

Lesser tributaries of Marsyangdi below $3000 \mathrm{~m}$ have narrow bottoms filled with coarse-grained material, steep long profile gradients, with depths of these valleys reaching 2000 metres. Torrential cones are formed in the area of confluence with the main tributary. In the summer monsoon time, the water from these valleys creates numerous cascades in the landscape and the water coming down from initial valley forms creates a number of waterfalls (position B on Fig. 1). 


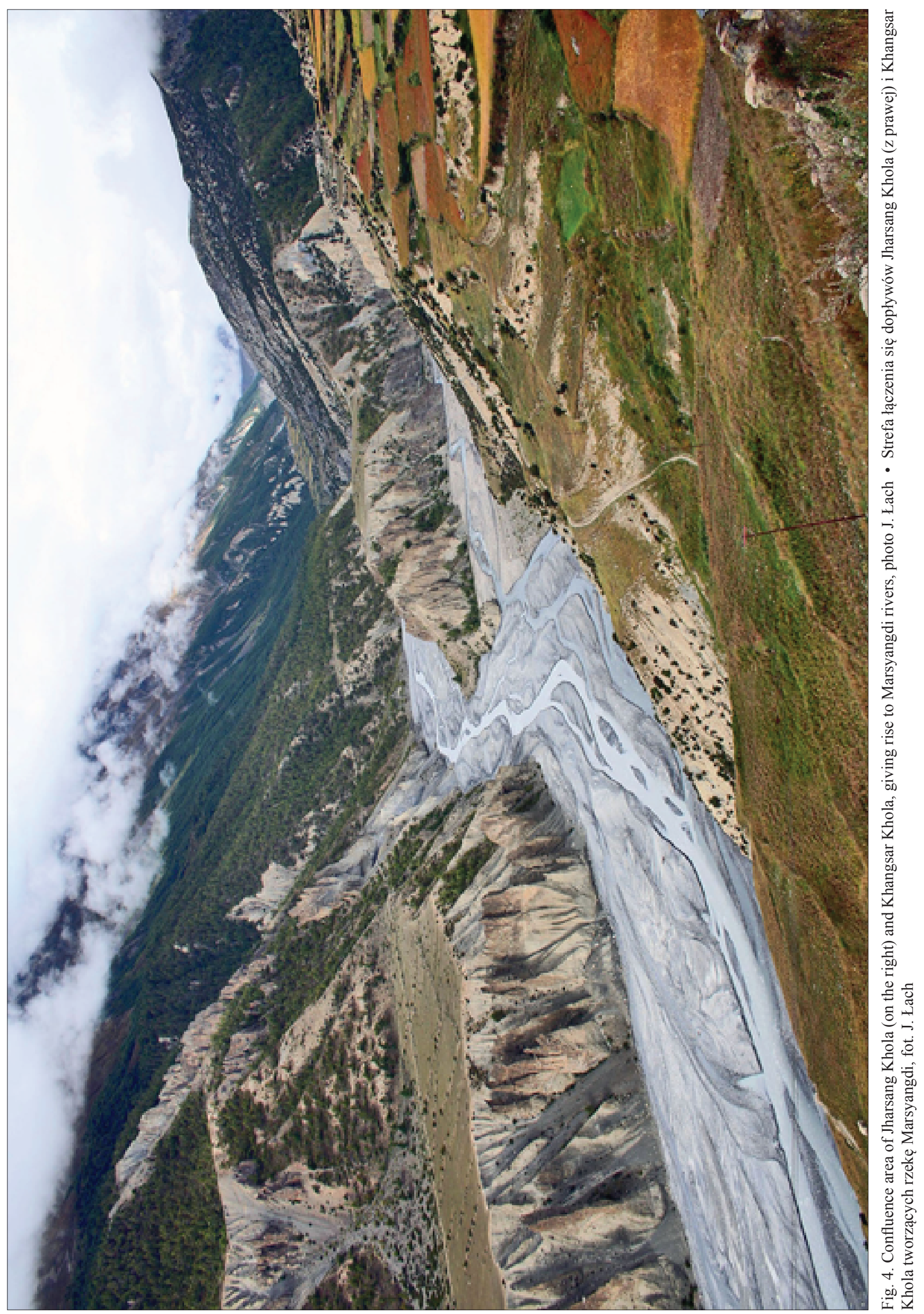




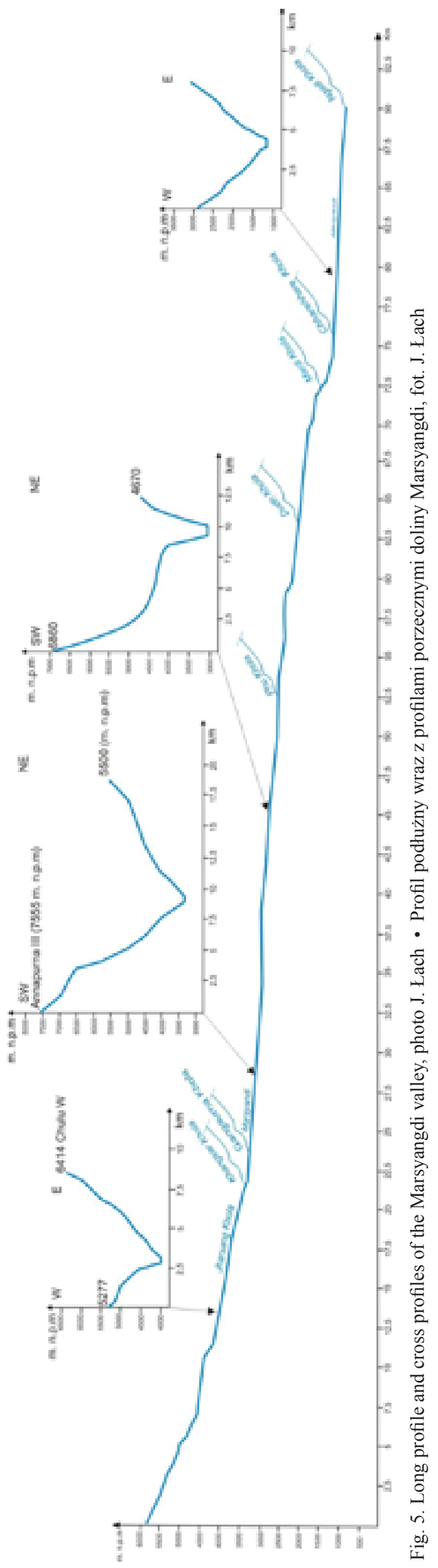




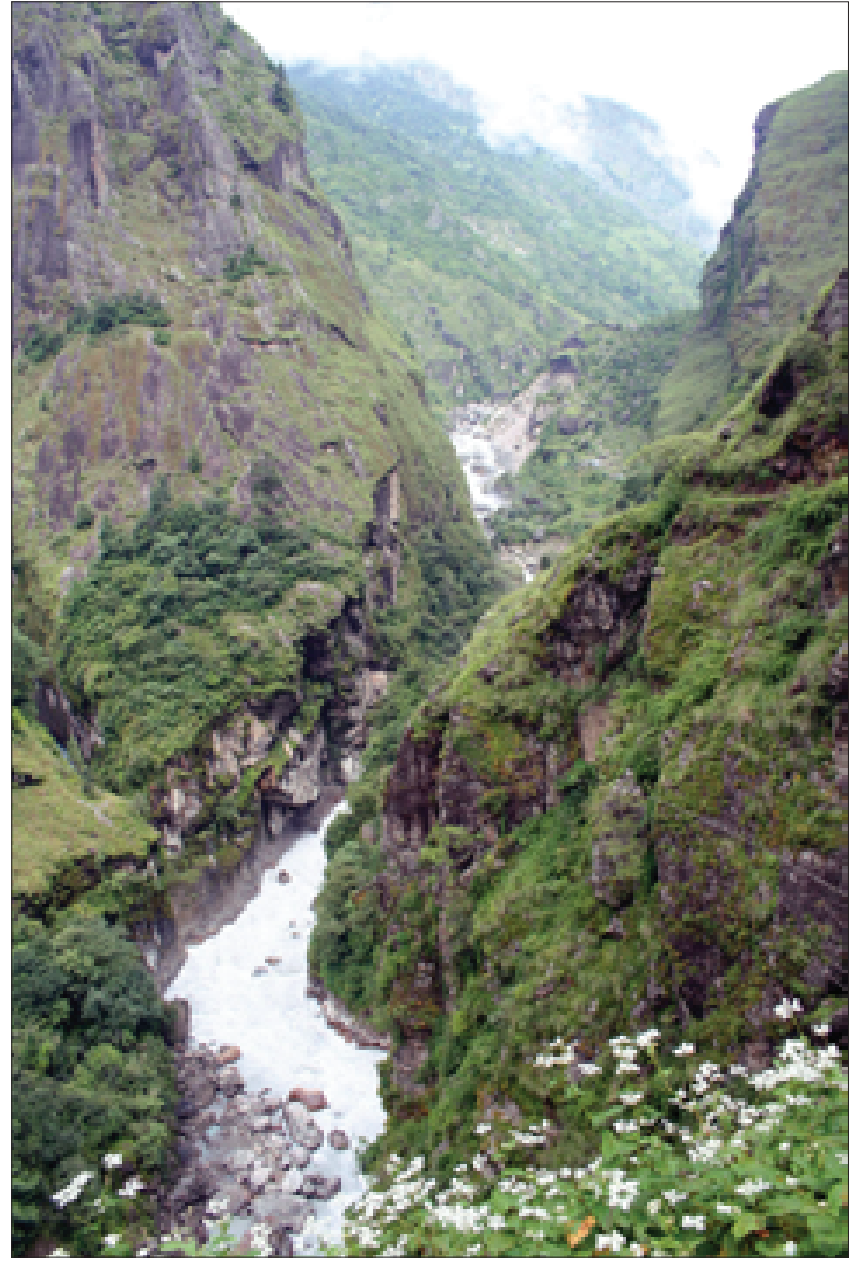

Fig. 6. Gorge in Marsyangdi river in the vicinity of Tal, photo J. Łach - Strefa przełomowa rzeki Marsyangdi w okolicy miejscowości Tal, fot. J. Łach

Above $3000 \mathrm{~m}$, however, postglacial forms become visible in the relief of the valleys. Currently, glacier termini come down to the altitude of around $4000 \mathrm{~m}$, below which terminal moraine ramparts accompanied by lateral moraines, reaching heights of 30-40 metres, are visible. The limnic area between the terminal moraine and the glacier terminus is home to alluvial fans, split by glacial meltwater forming braided channel system. Terminal moraine ramparts form post-glacial lakes filled with limnic sediment, which comes from the melting glacier. Currently, we can observe an intensive elevation process of coarse-grained material from the melting glaciers, which melt at an astonishing rate of $12 \mathrm{~m}$ per year (ACAP data 2008). Glacial processes occur presently only in the seepage spring area of the Marsyangdi Valley and its lateral tributaries e.g. in the Gangapurna Valley (Fig. 9, position C on Fig. 1) and Annapurna II Valley, above $4000 \mathrm{~m}$. The remaining part of the valley was cleared of glaciers leaving numerous post-glacial landforms.

Other features, in addition to forms developed by fluvial processes, visible in the morphology of the Marsyangdi

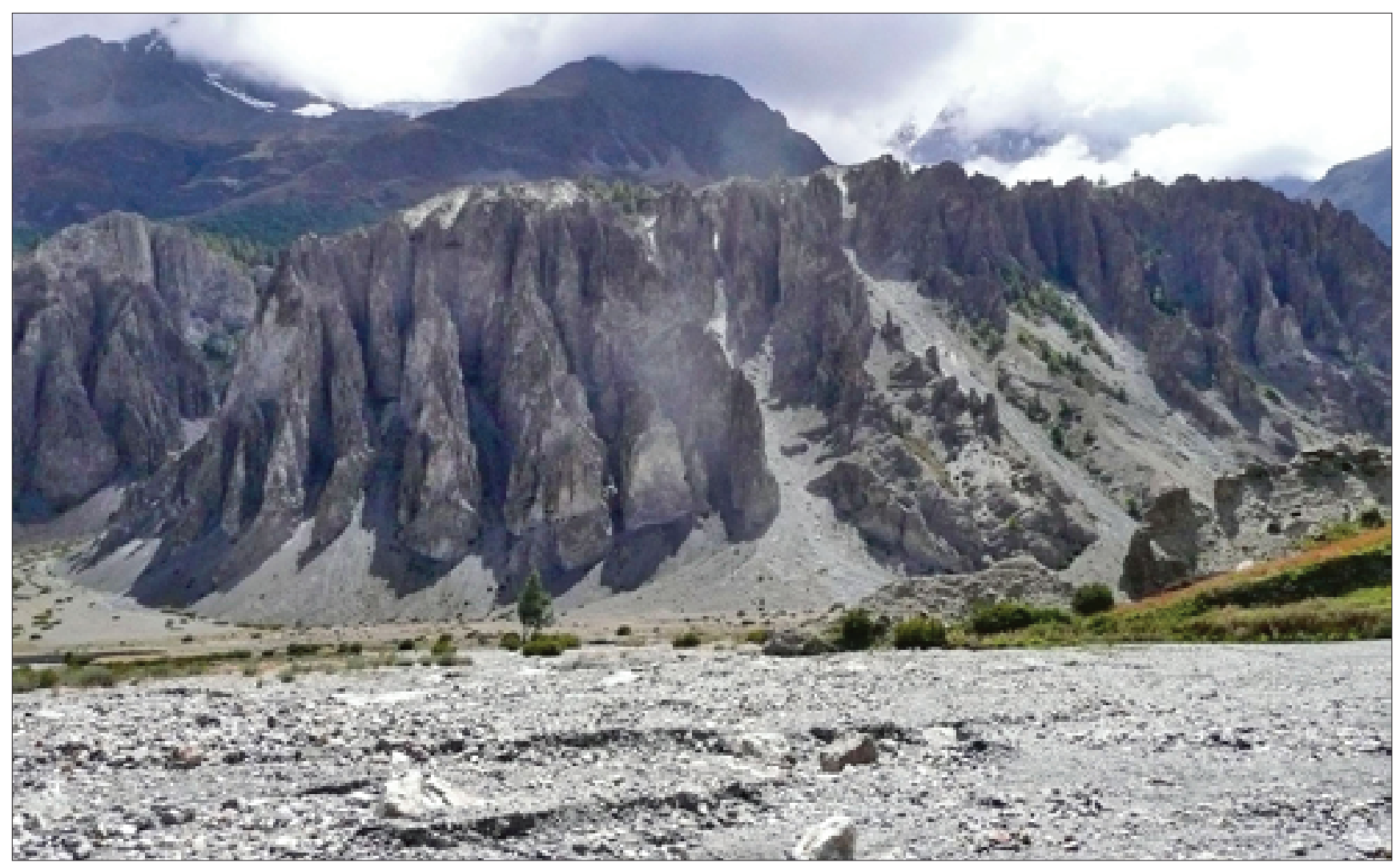

Fig. 7. Badlands landscape on lateral moraine in the Marsyangdi Valley in the vicinity of Manang, photo J. Łach • Krajobraz badlandu utworzony na morenie bocznej w dolinie Marsyangdi w okolicy miejscowości Manang, fot. J. Łach 
Valley, are mass movement forms. In the upper part of the valley called Jharsang Kola, frost weathering gives rise to rockfall processes and, under the pressure of weight, forms tremendous alluvial cones, which turn into alluvial heaps (position D on Fig. 1). The process of slope retreat is not always accompanied by a reduction in its steepness, which is visible in the relief as rock cliffs. Alluvial heaps, due to earthquakes, are unstable forms, which tend to continually move downhill (Fig. 10). Alluvial heaps are characterized by polygenic structures.

Another mass movement process observable in the valley is rock mass fall. Rock mass fall usually takes place in rock masses, built of glacial clay to form badlands landscape. Low rock mass cohesion, weathering process, erosion initiated by intense precipitation, earthquakes and human activity all trigger sediment collapse. Sediment, which often reaches the active river channel or limnic area, builds on the erosional base. The rock mass fall is made evident by numerous new exposures of rock mass. Another process in the Marsyangdi valley, especially between Manang-Bhulbhule, which creates new morphological forms, is landslide. The processes take place in the area of waste reaching the thickness of 3-4 metres. Intense precipitation, earthquakes and human activity (communication and transit road constructions) give rise to a number of translatory slides of planar areas, cut parallel to the slope. A range of slides, especially the ones that have arisen in communication routes, have no contact with flowing water. Anthropogenic slides (Fig. 11, position E on Fig. 1), however, due to their geology, morphology and meteorological phenomena on the slopes of the valley are undercut by flowing water classical slide forms developed: with slide niche, slide trough and slide heap.

Another visible form of mass movement is the form of debris and mud slides a few hundred metres in length. The debris flow that develops on steep slopes frequently reaches the active valley bottom, supplying coarse-grained (blocks and boulders) material to the channel (Fig. 12). The flows, especially in the slide trough area, reveal the structure of rock bottom, thereby determining their structural type. Sediment structure of the slides represents mud-debris type. An important example, from the perspective of morphology and landscape, is a huge, new slide in Bagarchap, which formed in 1995 and buried $75 \%$ of the locality (data obtained from ACAP workers).

The morphology of the slopes of the Marsyangdi valley also shows other rock forms: hoodoo, spires, rock cliffs and glacial polish. Below $2200 \mathrm{~m}$, the landscape is dominated by terrace fields (Fig. 13).

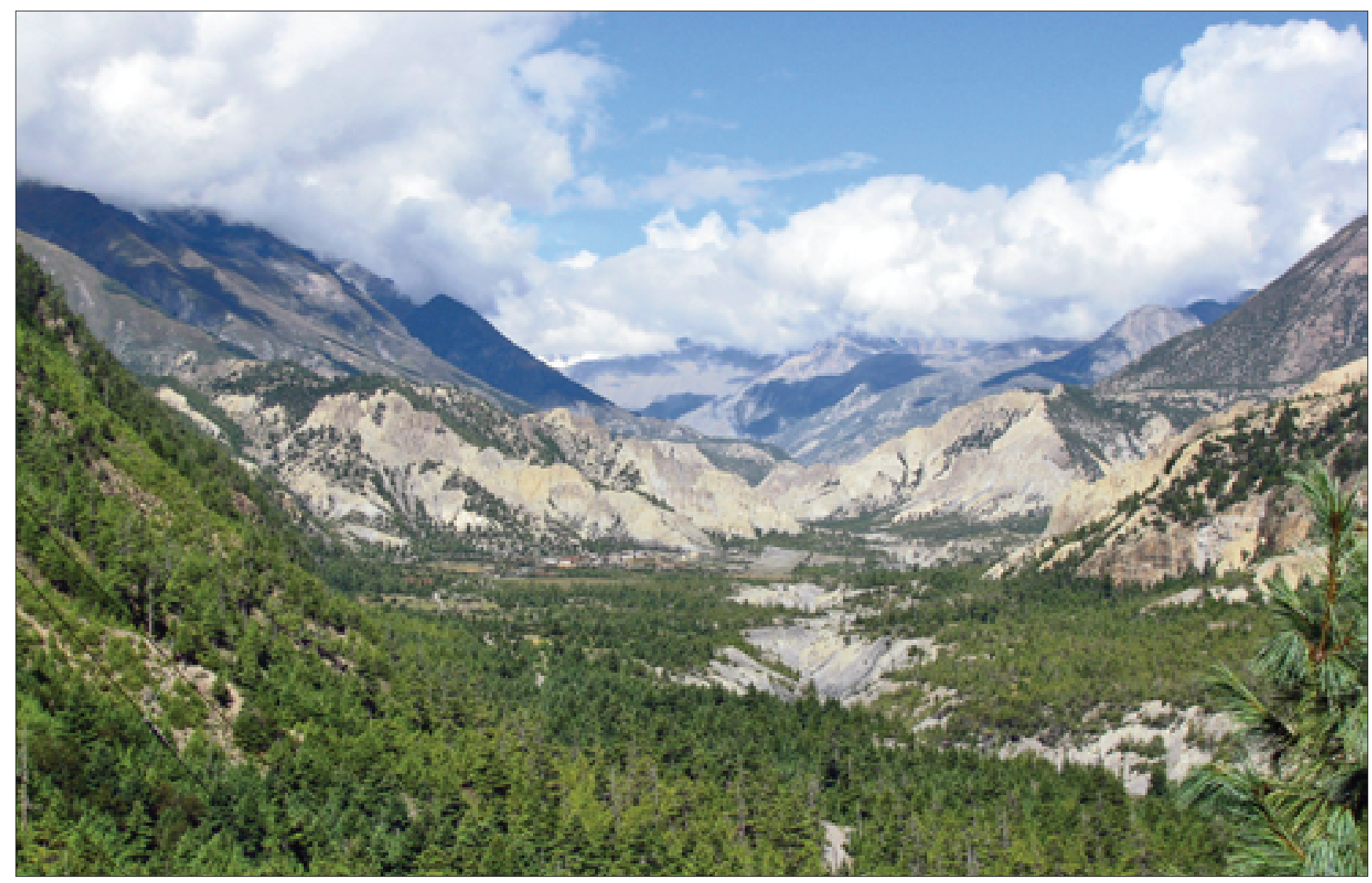

Fig. 8. Marsyangdi river valley filled with fluvio-glacial sediments in the vicinity of Baratang, photo J. Łach • Dolina rzeki Marsyangdi wypełniona fluwioglacjalnym osadem w okolicy miejscowości Baratang, fot. J. Łach 


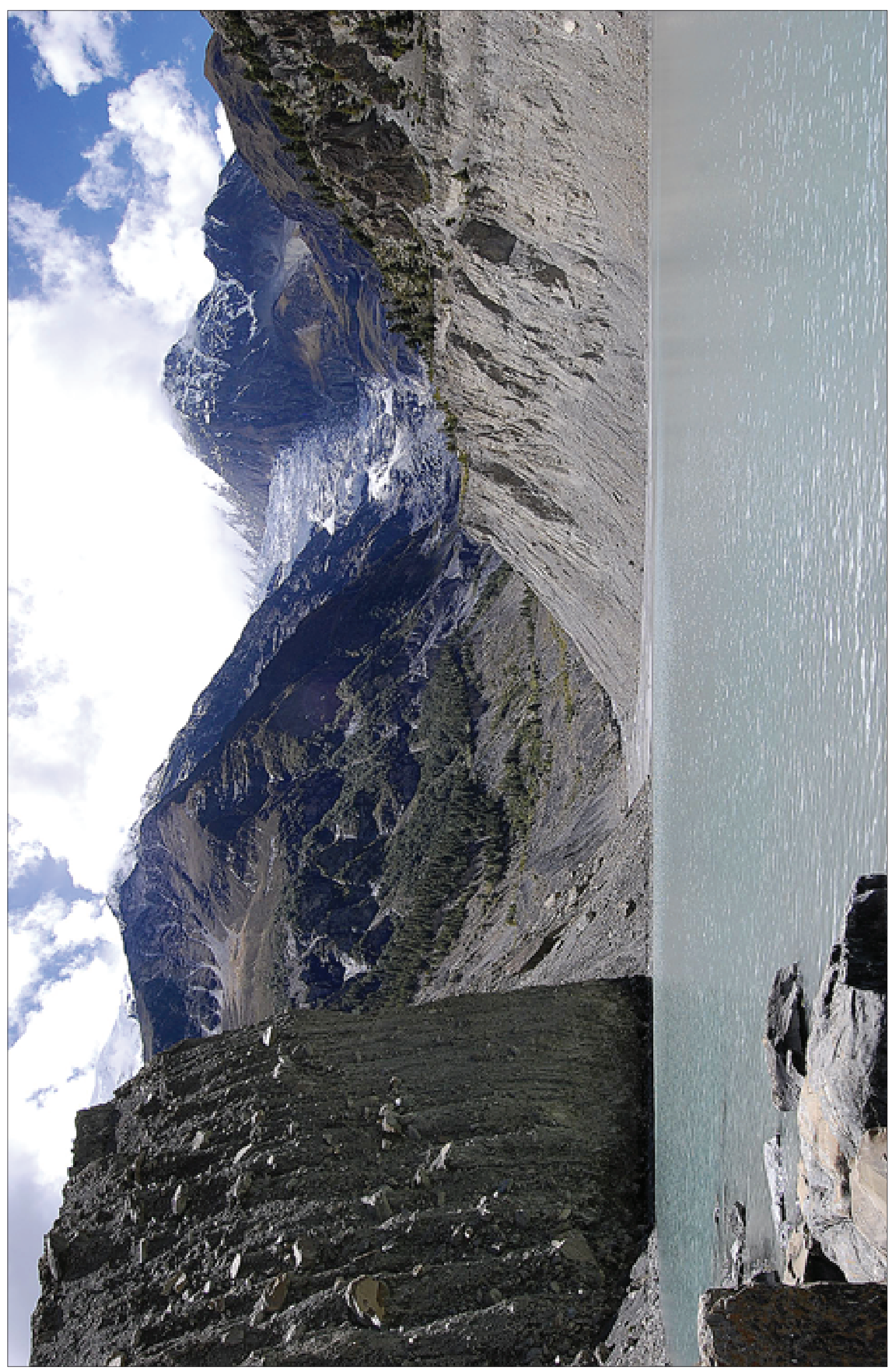

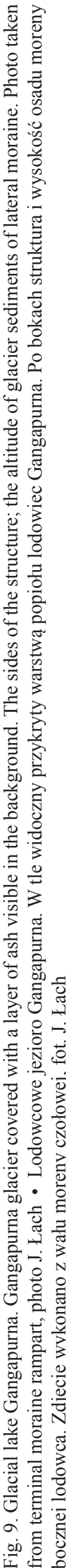




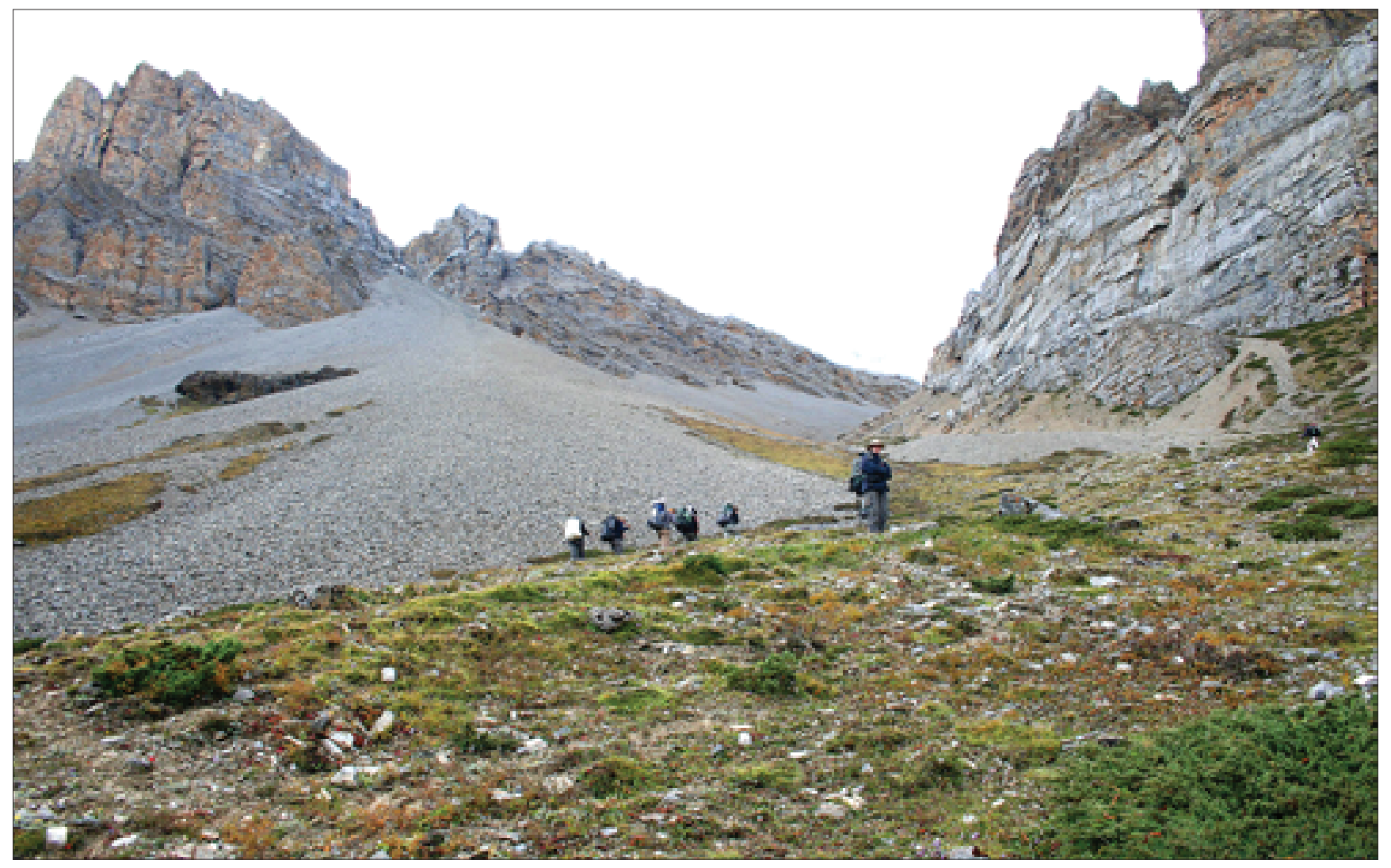

Fig. 10. Alluvial cone with visible rock cliffs in the Jharsang Khola valley in the vicinity of Thorung Phedi, photo J. Łach • Stożek usypiskowy z widocznymi klifami skalnymi w dolinie Jharsang Khola w okolicy Thorung Phedi, fot. J. Łach

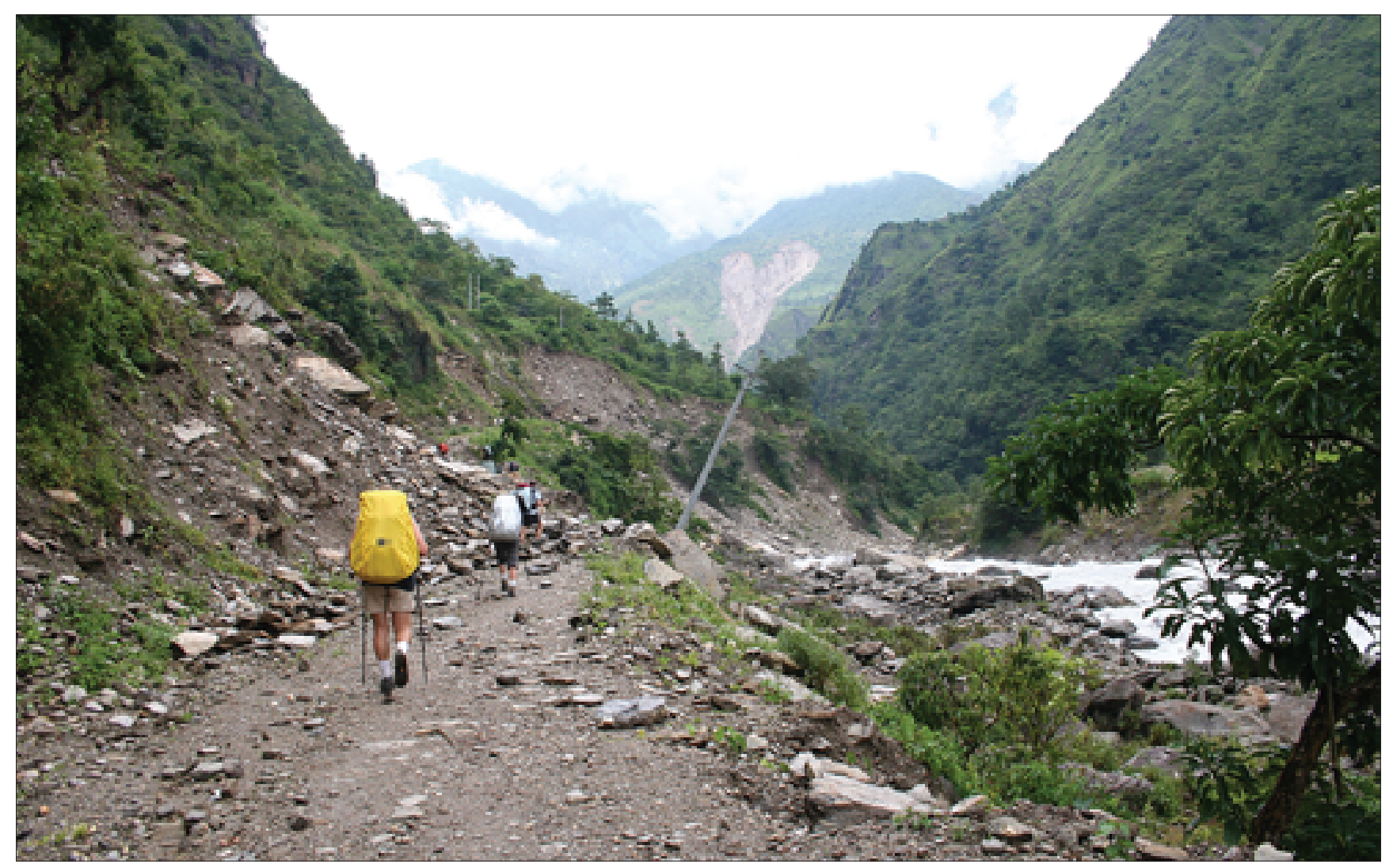

Fig. 11. Numerous anthropogenic slides in the Marsyangdi valley, photo J. Łach • Przykład licznych osuwisk antropogenicznych w dolinie Marsyangdi, fot. J. Łach 


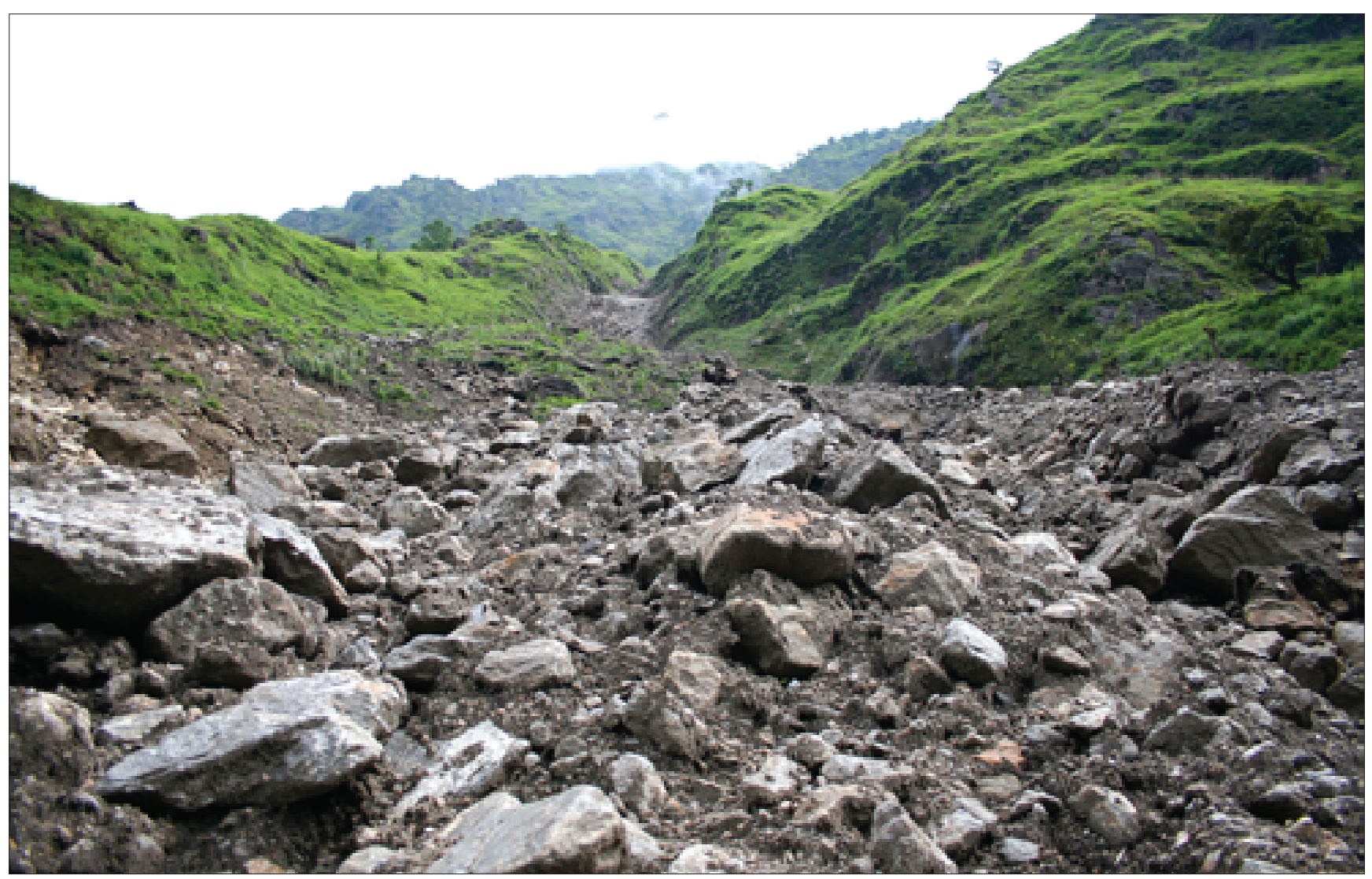

Fig. 12. Form and structure of the debris-mud flow $300 \mathrm{~m}$ long in the vicinity of Tal was formed in 2008, photo J. Łach • Forma i struktura spływu gruzowo-błotnego o długości ponad 300 m niedaleko miejscowości Tal, powstała w 2008 roku, fot. J. Łach

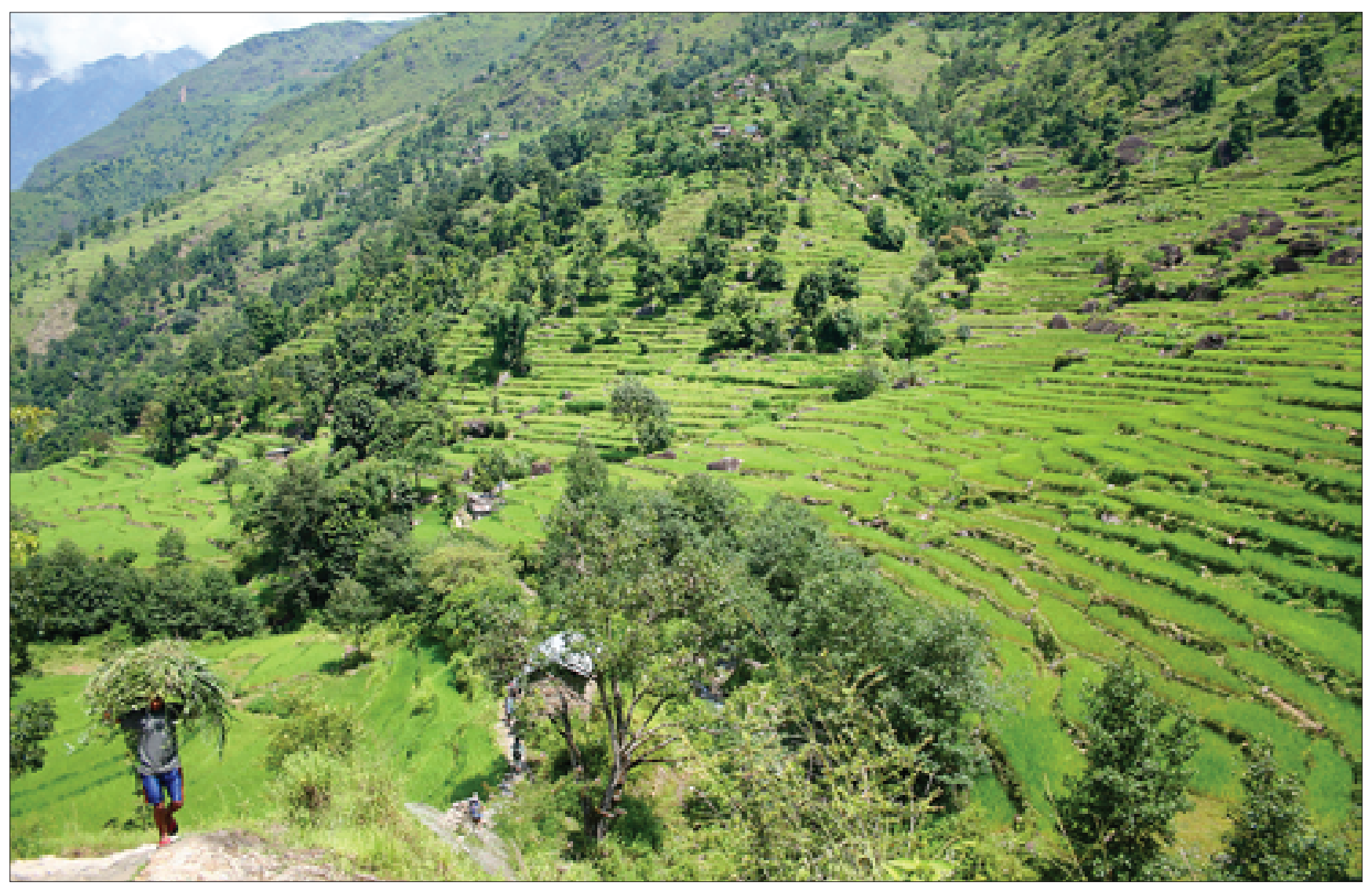

Fig. 13. System of rice terraces reaching $2200 \mathrm{~m}$ a.s.l. in the vicinity of Nagdi, photo J. Łach • System teras ryżowych sięgający wysokości 2200 m n.p.m. w okolicy Nagdi, fot. J. Łach 


\section{Human pressure on the shape of landscape in the context of geotourist value}

The Annapurna Himal region is characterized by an immense biodiversity of ecology and landscape and, as a result, huge differences in relative altitudes. The area is special with respect to its natural landscape - as has been shown above - but also in terms of cultural landscape which attracts huge numbers of tourists seeking trekking opportunities in Nepal. The region is inhabited by Gurung, Magar and Tamang peoples, who are predominantly Buddhist communities. The Gurung people, a group of mongoloid origin, inhabits mainly the southern slopes of the Annapurna Himal. The main sources of income for the inhabitants are shepherding and farming (potatoes, corn, rice, wheat, barley, oats, mustard plant), military salaries and tourist services. For years, they have also carried on trade with India and Tibet (Ramble, Brauen, 2008).

The Magar people also share typical mongoloid facial features i.e. full, round faces, flat noses, sharp cheekbones, narrow, slanting eyes and yellowish skin colour. They inhabit the area located between Annapurna and Dhaulagiri. In terms of nature and culture, the area is a combination of subtropical zone and scarce, high mountain vegetation, a melting pot of northern Buddhist and southern Hindu traditions. The Magar language belongs to the Tibeto-Burman family. The largest portion of the population is represented by small scale farmers growing barley and potatoes, who invest their savings in herds of yaks and earn their money on yak wool, skin and milk products. The Tamang people are an ethnic group inhabiting the eastern parts of the Annapurna region east of the Marsyangdi valley. They are mostly followers of Tibetan Buddhism, with the elements of Bon beliefs. They speak the Tamang language of Tibeto-Burman family. Tamang stands for "cavalryman" as the Tamang people used to serve as guardians of borders and, under British rule, many Tamang people served in Gurkha regiments. Presently, they grow rice, potatoes, keep goats, yaks, horses and work in the tourist industry (Bista, 1976; Shrestha, 2007).

Centuries-long existence of the aforementioned ethnic groups has largely shaped the harmonious cultural landscape at least until the mid-20th century. Starting from the late 80 's, there has been a period of dynamic changes in the spatial structure of settlement. In addition to farming and shepherding, which largely led to deforestation and terracing of slopes, an important role was played by tourism. It has helped to expand and accommodate the rural infrastructure for tourist purposes. Localities like Tal, Bagachap, Chame, Pisang or Manang saw new hotels erected, shops, control and tourist information points opened, whose architecture, frequently already made of local stone, differs from the traditional, wooden architectural style. Tourist hotels - as they are officially referred to - which are factually more like tourist shelters, and shops start to dominate the architecture in the Marsyangdi valley, giving way to typical, rural and religious buildings (Fig. 14).

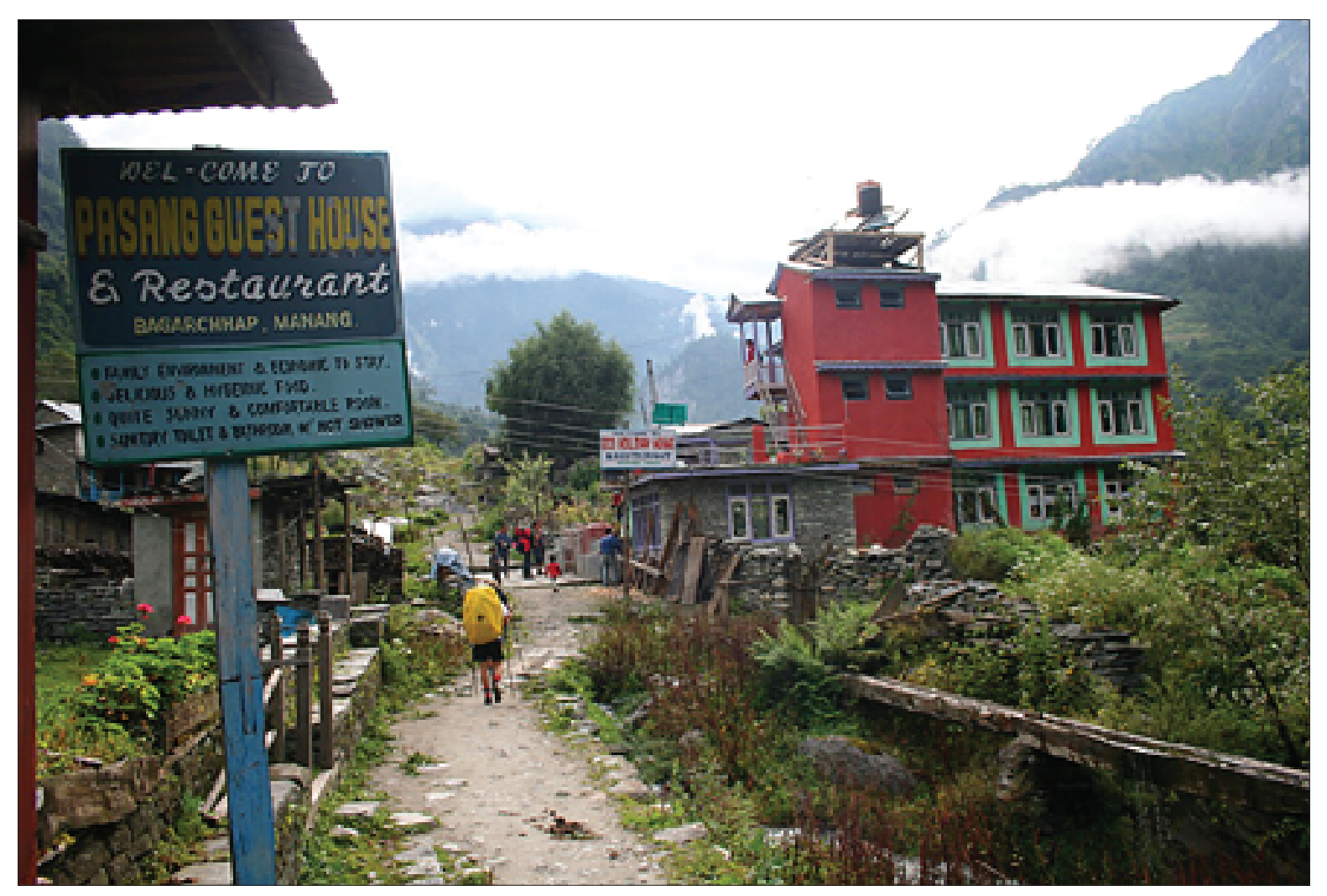

Fig. 14. Lack of harmony between modern hotel architecture and the surrounding landscape in Bagarchhap, photo J. Lach • Przykład współczesnej architektury bazy noclegowej nieharmonizującej z otaczającym krajobrazem w miejscowości Bagarchhap, fot. J. Łach 
An increasing number of tourists in the Annapurna region has a damaging effect on old, historical communication routes. New tourist routes are drawn using heavy-duty machinery, leading to the devastation of the landscape and development of numerous slides. Apart from the tourist industry, agriculture also brings about changes in the landscape by spreading to higher altitudes and leading to deforestation of the Marsyangdi valley.

The most spectacular changes in slope relief can be observed at 2200-2500 metres, as this is the upper altitude reached by rice terraces and their irrigation system. Up to 3500 metres, cultivation of potatoes and buckwheat has transformed the bottom of the valley. Above this height, cultivation discontinues and gives way to pasturing goats, cows and horses and, above the forest line in high mountain meadows, yaks. By removing the turf and creation of new paths, high mountain pasturing severely contributes to the degradation of slopes, which by way of erosion, turn into deep tunnel valleys.

Old cultural heritage stands out within the described landscape changes. It is an incredibly important historical, cultural and physiognomic element of the Annapurna region. The objects of high cultural and landscape value include religious buildings such as gompas (Fig. 15), stupas (Fig. 16), chortens (Fig. 17), mani walls (Fig. 18), kani gates (Fig. 19) and cult sites, which were built of local building material, gneiss mainly, within 100 years. A place which is amazing from the morphological, geological and spiritual perspective is Oble Dome, 4665 metres above sea level, which is located in the vicinity of the mountain ridge known as Paungda Danga. One homogeneous rock wall with clear glacial exaration is a sacred place for Buddhists and the followers of the Bon religion. Native people believe that the spirits of dead ancestors gather at the top just before setting out on their eternal journey to Tibet (Fig. 20).

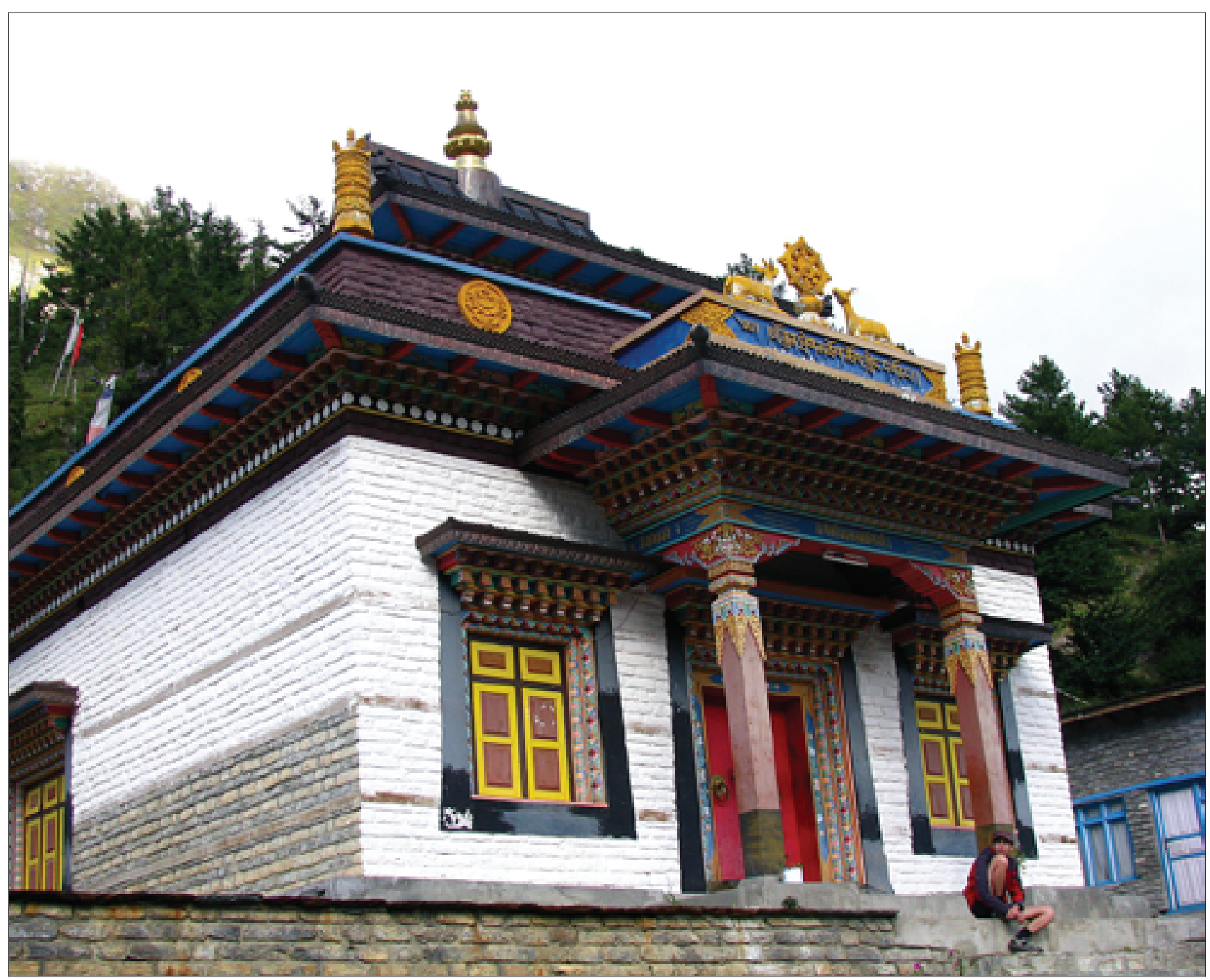

Fig. 15. Buddhist gompa in Upper Pisang built using local rocks (gneiss, schist), photo J. Łach • Buddyjska gompa w Upper Pisang zbudowana z wykorzystaniem miejscowego surowca skalnego (gnejsy, łupki), fot. J. Łach 


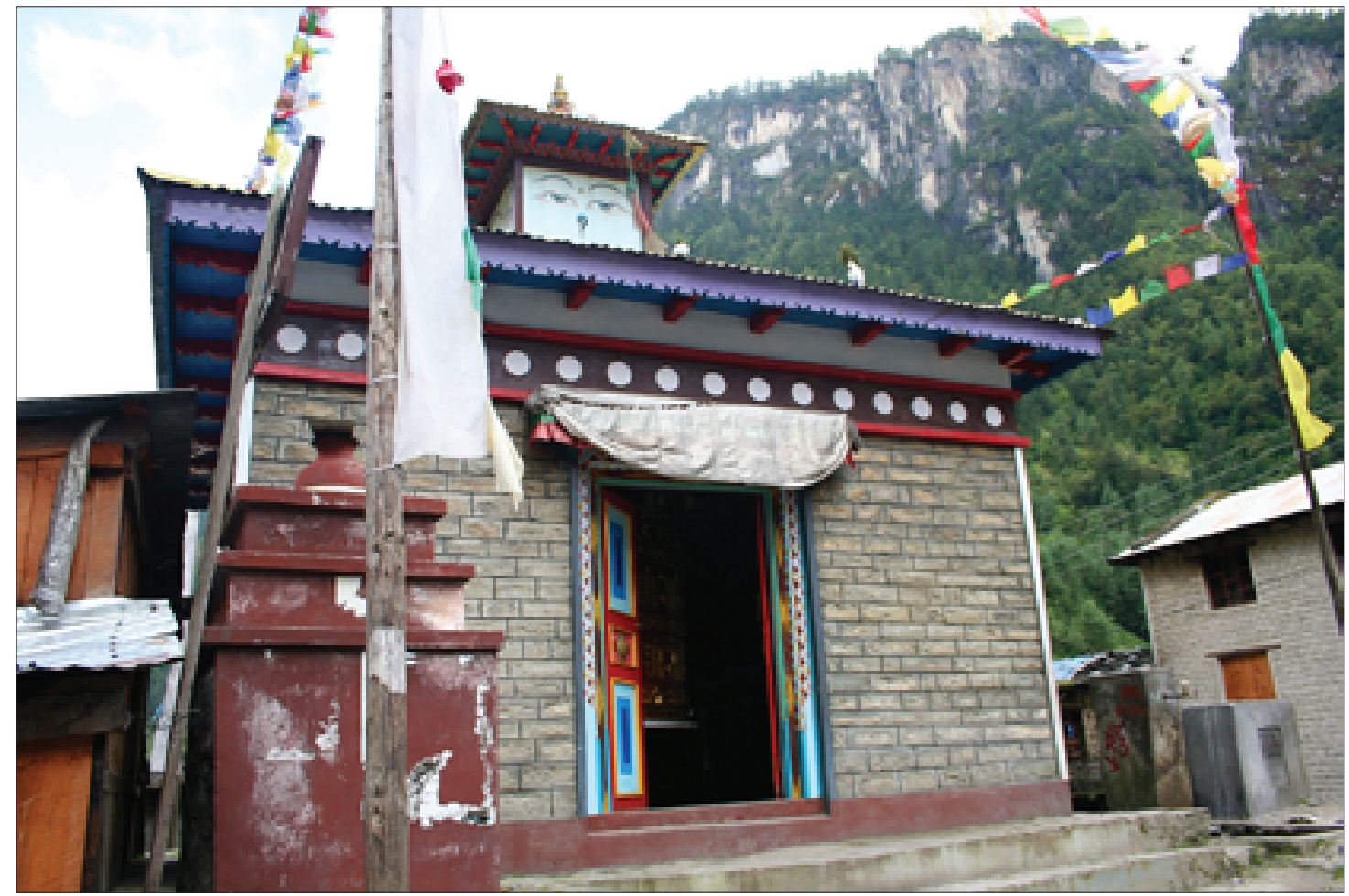

Fig. 16. Stupa in Chame, which houses the largest prayer mill, $2 \mathrm{~m}$ in diameter, in the Marsyangdi Valley. The sign says: Om Mani Padhme Hum ('Praise to the Jewel in the Lotus'). At the top of the tower there are four pairs of the All-seeing Buddha eyes looking in four directions of the world. The 30 year old object is accompanied by prayer flags, photo J. Lach • Stupa w Chame mieszcząca największy w dolinie Marsyangdi młynek modlitewny średnicy dwóch metrów z napisem Om Mani Padhme Hum (Bądź pozdrowiony klejnocie ukryty w kwiecie lotosu). Na szczycie wieży widoczne są cztery pary oczu wszystkowidzącego Buddy, patrzące w cztery strony świata. Obiektowi liczącemu 30 lat towarzyszą flagi modlitewne, fot. J. Łach

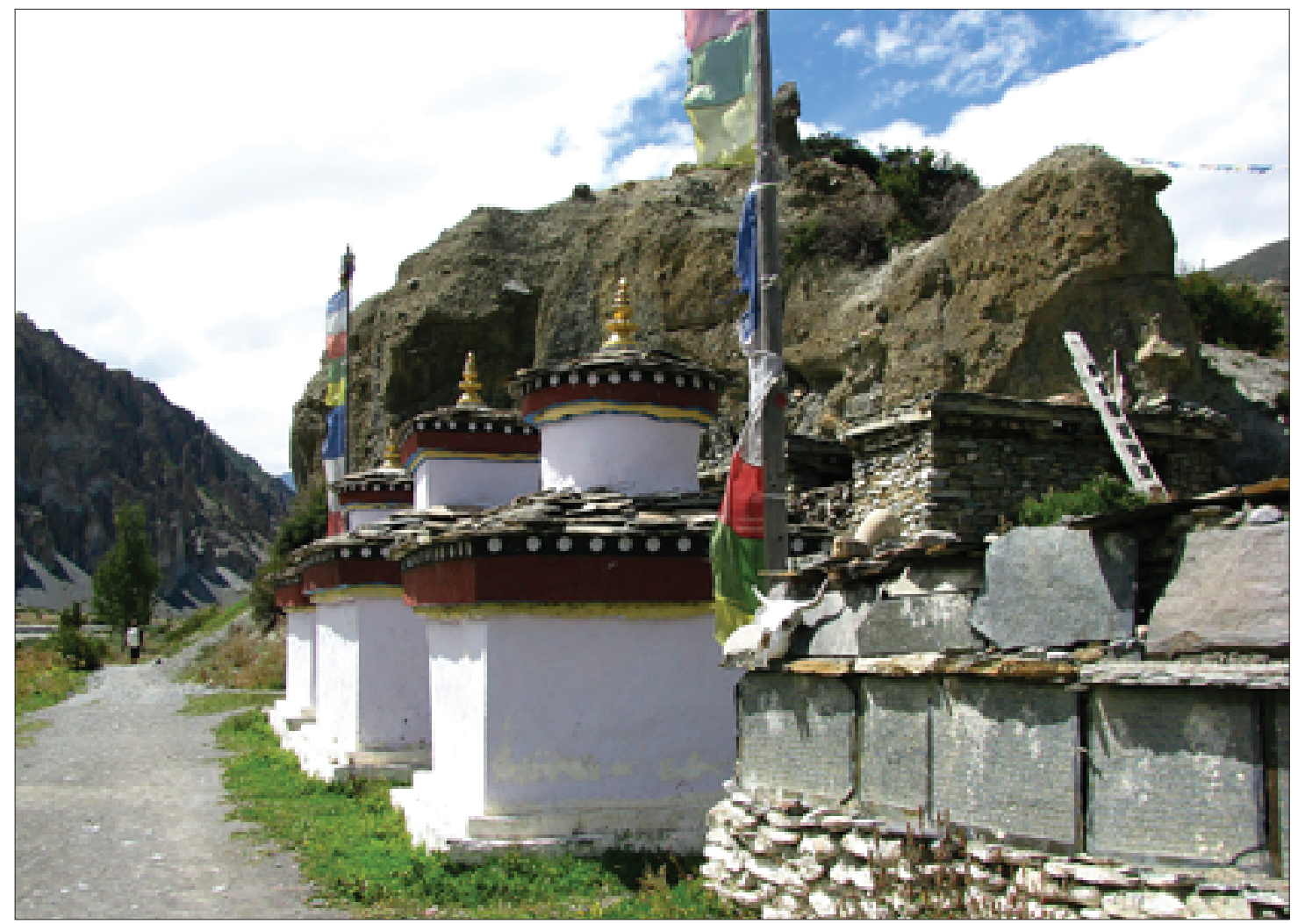

Fig. 17. Eight Kyung chortens (on the way to Manang village). Older buildings on the right are covered with flat, stone (schist) tables with engraved prayer texts. The age of the chortens is estimated to be 100 years, photo J. Łach • Zespół ośmiu czortenów Kyung (przy szlaku do wioski Manang). Starsze budowle z prawej strony obłożone są płaskimi kamiennymi (łupkowymi) tablicami z wyrytymi tekstami modlitw. Wiek czortenów szacuje się na 100 lat, fot. J. Łach 


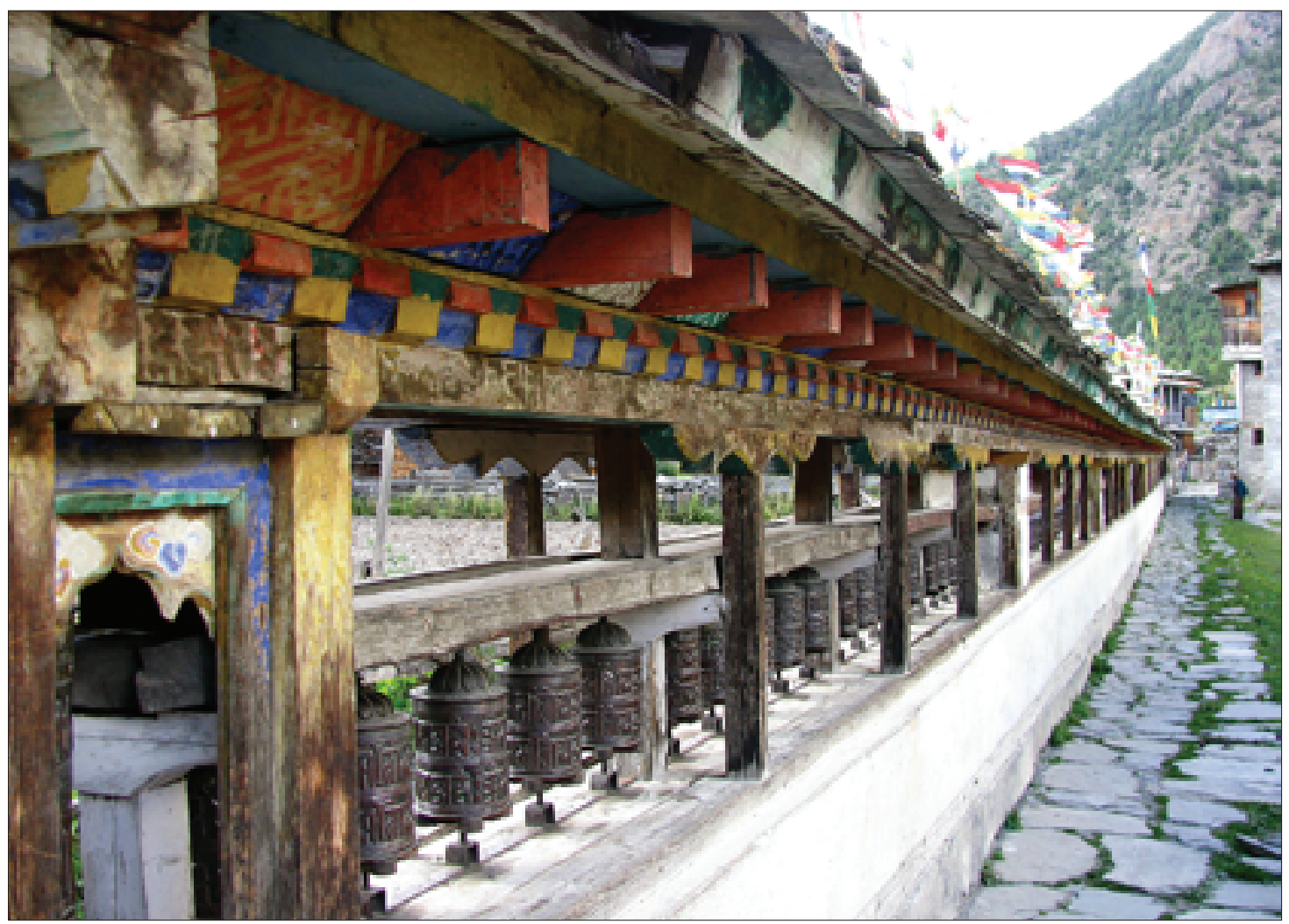

Fig. 18. The longest mani wall in the valley in Lower Pisang. The object was built in 1980's, it is about 150 metres long and contains about 50 prayer mills, photo J. Łach • Najdłuższy w dolinie Marsyangdi murek mani w Lower Pisang. Obiekt powstały w latach 80 . XX wieku, liczy około 150 metrów długości, mieści ponad 50 młynków modlitewnych, fot. J. Łach

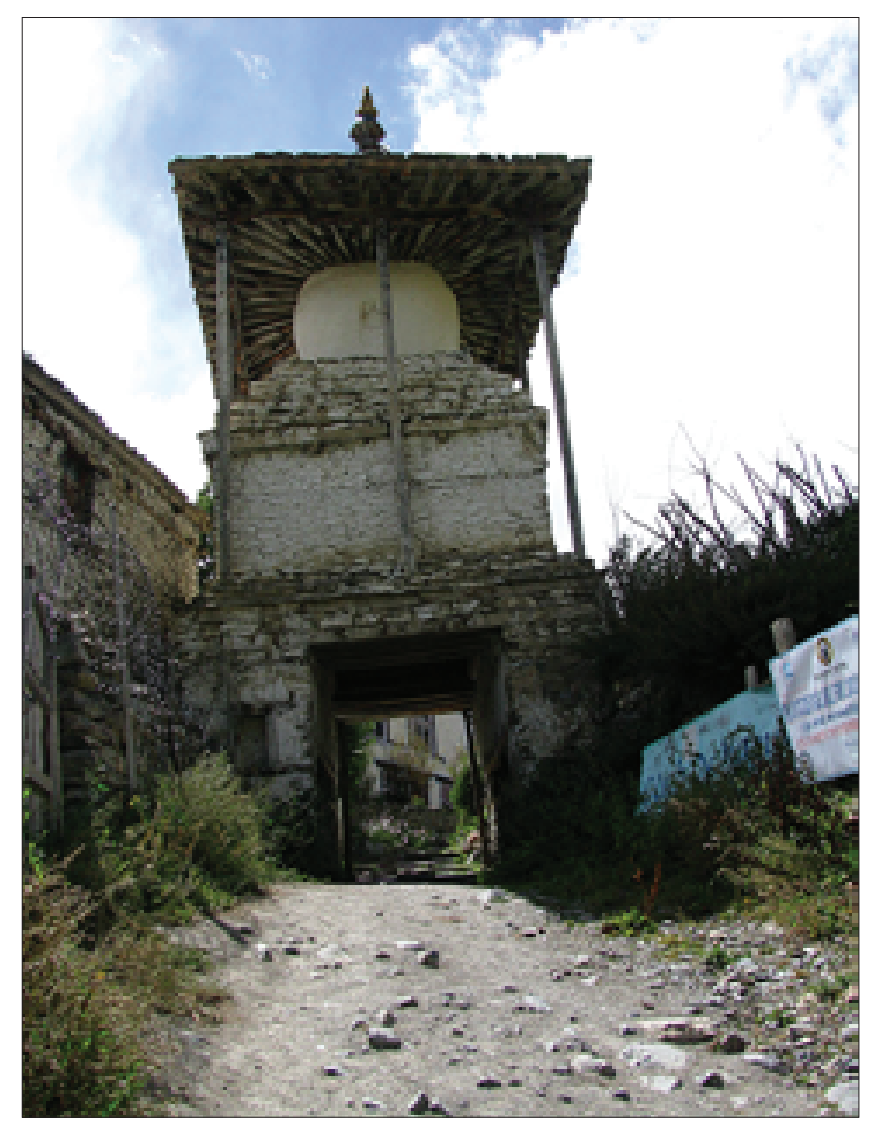

Fig. 19. 150 year old kani gate in Manang. A stone (gneiss) structure was erected at the entrance to Buddhist village, prayer mills on its sides, photo J. Łach - 150-letnia brama kani w Manangu. Kamienna (gnejs) budowla stawiana była na wejściu do wioski buddyjskiej, po jej bokach zainstalowane są młynki modlitewne, fot. J. Łach 


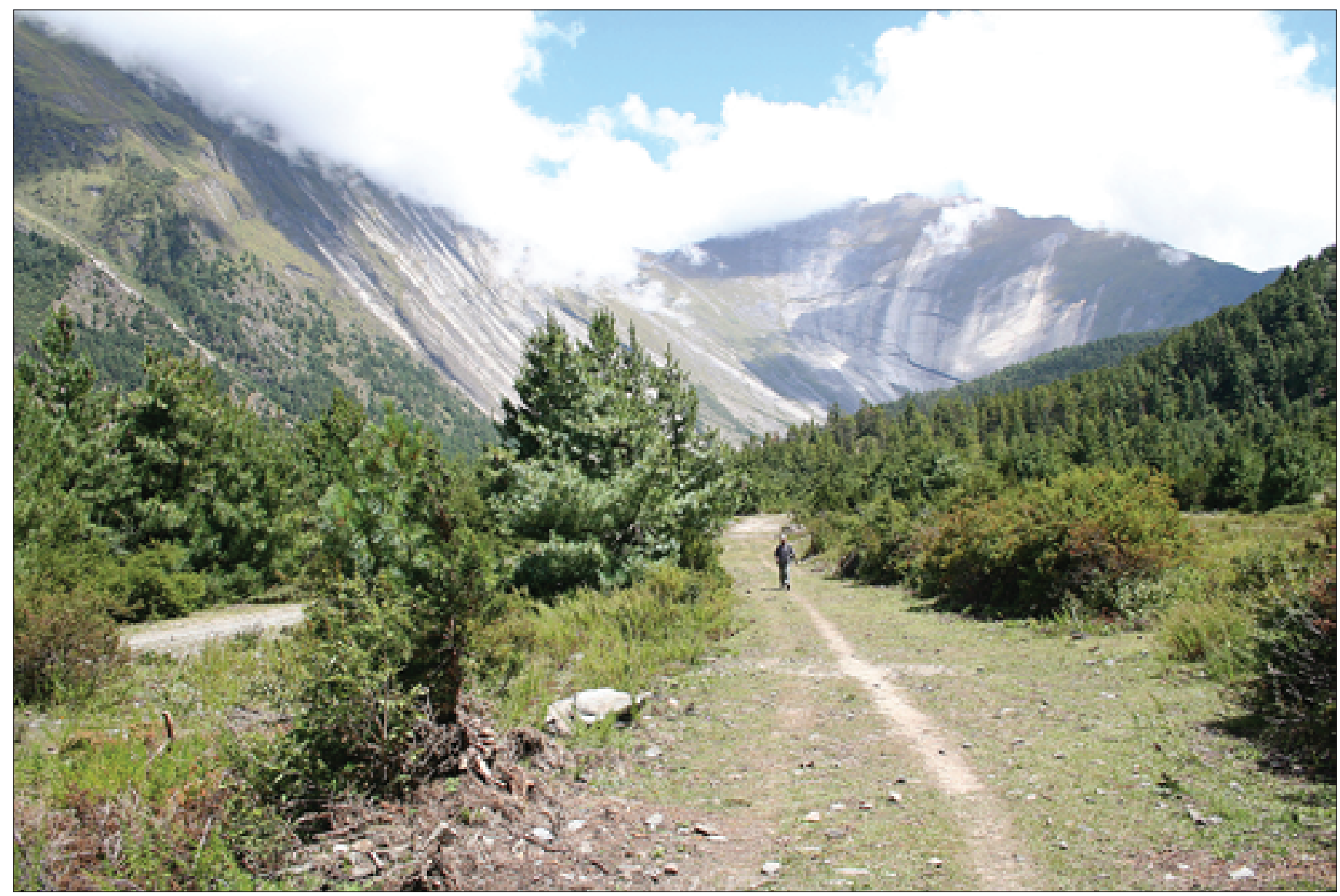

Fig. 20. An amazing geological and morphological form known as Paungda Danga (Oble Dome $4665 \mathrm{~m}$ a.s.1.) which is a cult site of Buddhists and the followers of Bon religion (position F on Fig.1), photo J. Łach • Niezwykła geologiczno-morfologiczna forma nazywana Paungda Danga (Oble Dome 4665 m n.p.m.) będąca miejscem kultu buddystów i wyznawców Bon (Fig. 1. poz. F), fot. J. Łach

\section{Summary}

The valuation of the Marsyangdi, with respect to geotourist facilities and phenomena and, in particular, to geomorphological and hydrographic elements demonstrated a huge diversity of forms and, consequently, a huge potential for geotourist attractions. The structure of the Marsyangdi valley, which is a representative of the High Himalayan valleys based in metamorphic rocks - predominantly gneiss, schist and migmatite, shows the coexistence of three distinct geomorphological processes: glacial, fluvial and slope. The upper reaches of the valley, up to approximately $4000 \mathrm{~m}$, are dominated by glacial processes and by fluvial and slope processes below. The range of the morphological processes allows the relief to be described as glacial-fluvial-denudational; from springs to $2800 \mathrm{~m}$ as nival, glacial and fluvio-glacial relief, from $2800 \mathrm{~m}$ to $800 \mathrm{~m}$ as fluvial relief with clear anthropogenic influences.

Numerous mass movement forms are noted in the slope relief, however, in valley bottom relief we can observe deep erosional channels, with a narrow riverbed of coarse-grained sediment. Noteworthy is the altitude of river terraces, which become lower as the river altitude becomes higher, resulting from gradual reduction in the deepening of the valley bottom produced by reverse erosion. The present dynamic of the morphological processes is affected by seismic processes, climatic and meteorological phenomena. In the upper reaches of the valleys, snowfall contributes to the formation of mountain-valley glaciers, and rainfall in the lower parts triggers sudden river swells, characterized by mixed transport activating block-boulder fraction. Torrential rains also initiate mass movement on valley slopes and mountain sides, exemplified by multiple slide forms.

Since the end of $20^{\text {th }}$ century until now, the landscape values of the Himalayan valleys have been largely shaped by anthropogenic factors. High mountain pasturing severely contributes to the degradation of slopes by removing the turf and creation of paths, which by way of erosion, turn into deep tunnel valleys and trigger landslides during rainfalls and earthquakes. Below the pasture zone to about 2500 metres above sea level, extensive rice cultivation on terraced slopes takes place. Flat riverbed valleys are, on the other hand, cultivated for potatoes or buckwheat up to $3500 \mathrm{~m}$ (in the case of the Marsyangdi valley). The range of most significant anthropogenic changes has currently reached around 3500 metres above sea level. 
The tourist interest in the Annapurna region presently has an immense effect on the transformation of the natural and cultural landscape. The necessity to build tourist infrastructure leads to the degradation of narrow riverbed areas, through the construction of chaotic settlements and extension of networks of tourist trails, giving rise to an increased activity of mass movements and formation of erosional channels in communication routes. Absence of water pipelines and sewage systems leads to the pollution of the environment with communal waste. Apart from the negative effect tourism exerts on the natural environment, it also is noteworthy to mention its positive aspects in relation to cultural heritage and, in particular, the fact that a number of objects of cultural interest, which largely dominate the landscape and represent indisputable tourist attractions in the region, have been renovated and are on display today. The material clearly shows that the Marsyangdi valley represents a qualified exploratory tourism area defined as a geotourist region representing the

\section{References (Literatura)}

Around Annapurna - trekking map, 2004. Copy by Map Piont, scale $1: 125$ 000, Nepal.

Bista D.B., 1976. People of Nepal. Ratna Pustak Bhandar, Kathmandu.

Dahal R.K., 2006. Geology of Nepal, Department of Geology. Tribhuvan University, Ghantaghar, Kathmandu, Nepal (www.ranjan.net.np).

Golonka J., 2009. Phanerozoic paleoenviroment and paleolithofacies maps. Cenozoic. Geologia, 35(4): 507-587.

Golonka J., Krobicki M., Pająk J., Van Giang N., Zuchiewicz W., 2006. Global plate tectonics and paleogeography of southheast Asia. AGH University of Science and Technology, Krakow, Poland.

Kowalczyk A., 2010. Turystyka zrównoważona. PWN, Warszawa.

ŁajczakA., 2007. Krajobrazy dolin Wyżyny Tybetańskiej. In: Myga-Piątek U. (ed.), Doliny rzeczne. Przyroda - krajobraz - człowiek. Prace Komisji Krajobrazu Kulturowego PTG, Sosnowiec, 7: 71-90.

Makowski J., (ed.) 2006. Geografia regionalna świata. Wielkie regiony. PWN, Warszawa.

Modela R., 2000. Przeglądowy atlas świata. Azja część 1, 2. Oficyna Wydawnicza Fogra, Kraków.

Narkiewicz M., 1997. Problemy budowy i ewolucji geologicznej Himalajów i Tybetu na XXX Międzynarodowym Kongresie Geologicznym w Pekinie. Przegląd Geologiczny, 45(5): 476-483.
High Himalayan area. The part of the valley under examination has the potential of geotourist - geomorphological trail, as it is full of the most important and interesting geomorphological attractions. Nevertheless, without the introduction of proper geological and geomorphological knowledge in the form of tourist signs or guidebooks, for individuals with expertise in natural sciences the current route is only a qualified-trekking trail.

The study necessitates working out more precise methods of valuation of geotourist objects and sites in high mountain areas and conducting further field studies. From the point of view of a geomorphologist, it also seems necessary to develop and elaborate a study of geotourist trails.

\section{Acknowledgements}

Special thanks for Siddhartha B Bajracharya, PhD Executive Director National Trust for Nature Conservation Khumaltar, Lalitpur, Nepal.

Osadczuk A., Osadczuk K., 2008. Szanse i perspektywy rozwoju geoturystyki jako nowej formy postrzegania obiektów przyrody nieożywionej i poznania zjawisk naturalnych. In: Dutkowski M. (ed.), Problemy turystyki i rekreacji, 1. Oficyna IN PLUS, Szczecin:131-141.

Popularna encyklopedia powszechna. Kontynenty i Państwa - Azja, 2000. Grupa Wydawnicza Bertelsmann, Warszawa.

Ramble Ch., Brauen M., 2008. Anthropology of Tibet and the Himalaya. Wadżara Publishing, Nepal.

Scheidegger A.E., 1998. Tectonic predesign of mass movements, with examples from the Chinese Himalaya. Geomorphology, 26(1): 37-46.

Searle M.P., 1996. Cooling history exhumation and kinematics of the Himalaya-Karakorum-Tibet orogenic belt. In: Yin A., Harrison T.M. (eds), The tectonics of Asia. Cambridge University Press, New York, 110-137.

Shrestha V.P., 2007. A concise geography of Nepal. Mandala Publishing, Kathmandu.

Słomka T., Kicińska-Świderska A., 2004. Geoturystyka - podstawowe pojęcia. Geoturystyka, 1(1): 5-7.

Trek around Annapurana, Annapurna Sanctuary. Copy by Sherpa Maps 2004. Scale $1: 160000$, Nepal.

Xiao X., Li G., Chang C., Yuan X., 1988. Tectonic Evolution of Lithosphere of the Himalayas. Geological Publishing, House, Beijing, China.

Zgorzelski M., 2009. Piętrowość krajobrazów Azji Centralnej. Prace i Studia Geograficzne, 41: 245-260.

\section{Websites}

www.ntnc.org.np/project/annapurna-conservation-area-project 